\title{
Research on the Impact of Government R\&D Funding on Regional Innovation Quality: Analysis of Spatial Durbin Model Based on 283 Cities in China
}

\author{
Jing Li $\mathbb{D}$ and Xinlu Wu $\mathbb{C}$ \\ Business School, Nanjing Normal University, Nanjing 210023, China \\ Correspondence should be addressed to Jing Li; lijing_hp@126.com
}

Received 8 April 2021; Accepted 1 July 2021; Published 9 July 2021

Academic Editor: Baogui Xin

Copyright (c) 2021 Jing Li and Xinlu Wu. This is an open access article distributed under the Creative Commons Attribution License, which permits unrestricted use, distribution, and reproduction in any medium, provided the original work is properly cited.

\begin{abstract}
Based on the perspective of the regional innovation system, this study constructs an analytical framework for the influence of government R\&D funding on regional innovation quality and uses 283 Chinese cities as research samples to empirically test the influence of government R\&D funding methods such as subsidies and tax preferences on regional innovation quality by the spatial Durbin model. According to the study, China's regional innovation quality has a positive spatial correlation. Subsidies can improve regional innovation quality, which is mainly realized by increasing the input of innovation resources from local direct innovation subjects, attracting the inflow of innovation resources from neighboring areas, and increasing the innovation support from local indirect innovation subjects. Besides, spatial competition for subsidies makes it beneficial to improve the regional innovation quality in neighboring regions, while the promotion effect of tax preferences is not significant. When considering the heterogeneity of the city location and administrative hierarchy, it shows that the government R\&D funding cannot improve the innovation quality of the Eastern cities and higher-administrative-hierarchy cities, while it can improve that of the Middle and Western cities and general-administrative-hierarchy cities. Furthermore, government R\&D funding widens the gap of regional innovation quality, which may be related to the existing "insufficient intervention" and "excessive intervention" of government $\mathrm{R} \& \mathrm{D}$ funding. This study provides insights into the implementation of R\&D funding by the government to promote the development of regional innovation quality.
\end{abstract}

\section{Introduction}

In the context of China's economic development model changing from resource-driven to innovation-driven, innovation has increasingly become the key to promoting high-quality development. It has become an objective requirement of China's economic growth to improve innovation quality and promote high-quality development through high-quality innovation [1]. While the Global Innovation Index 2019 shows that, in 2019, China's innovation output index ranked 5th globally, but its innovation quality index only ranked 15th, proving that China is facing the innovation dilemma of high quantity but low quality. Therefore, how to improve the quality of innovation has become an urgent issue in the process of innovation development. In the regional innovation system, firms, universities, and research institutions are the main subjects of innovation activities. However, the public nature of innovation makes innovation subjects less motivated to carry out high-quality innovation, leading to a lack of high-quality innovation activities. In this context, as additional innovation resources, government R\&D funding in the form of subsidies and tax preferences effectively strengthens regional innovation resources and stimulates innovation activities, and hence, it has been adopted by most countries around the world [1-4].

While the current practice of $R \& D$ funding by the Chinese government may be problematic in two ways: on the one hand, the increasing intensity of funding has had a limited effect on improving regional innovation quality. 
Taking subsidies as an example, China's local fiscal S\&T expenditure increased from 188.588 billion yuan in 2011 to 520.638 billion yuan in 2018 , with an average annual growth rate of $25.15 \%$, which was much higher than the growth rate of GDP in the same period (the growth rates of subsidies and GDP are calculated based on raw data from the China Statistical Yearbook). The increasing funding does not significantly improve regional innovation quality but raises concerns about creating an illusion of innovation [5]. Thus, it is necessary to deeply examine the effect of government R\&D funding on regional innovation quality and its mechanism. On the other hand, the increasingly tightening of fiscal revenue puts higher requirements for implementing government R\&D funding precisely. The State Council Government Work Report 2021 states that a total of 2.60 trillion yuan in tax cuts and fee reductions have been achieved throughout 2020, and it is expected that systematic tax reduction policies will continue to be implemented in the coming year. The continued increase in tax cuts has put local governments under unprecedented financial pressure, indicating that government $\mathrm{R} \& \mathrm{D}$ funding cannot be increased indefinitely. Coupled with the rigidity of local governments' fiscal expenditures, it is particularly critical to improving the efficiency of fiscal funds [6]. Meanwhile, it is necessary to clarify its impact on different regions to fund more efficiently and enhance regional innovation quality.

The impact of government R\&D funding on innovation activities has received extensive attention from scholars at home and abroad, and relevant studies have been mainly conducted in three aspects as follows. (1) The impact of government R\&D funding on the quantity of innovation. These studies focus on the input and output dimensions of innovation, and the conclusions are broadly presented as the positive effect $[7,8]$, the negative effect $[4,9]$, and the uncertain effect [10]. (2) The impact of government R\&D funding on the quality of innovation at the firm level. Firms tend to spend their efforts pursuing innovation quantity rather than innovation quality to cater to the government's preference for the scale and speed of innovation [11]. In this situation, previous studies based on innovation quantity may overestimate the effects of government R\&D funding. Thus, some studies have begun to examine its effect on innovation quality at the firm level. Dang and Motohashi [12] found that subsidies for patent filing and examination fees cannot incentivize firms to improve patent quality but instead trigger them to file low-quality patents strategically. However, also based on firm data, some scholars reach opposite conclusions. Ernst et al. [13] showed that taxes distort the quality of $R \& D$ projects and that reducing the patent income tax rate can improve patent quality. Mukherjee et al. [14] found that, with the increase of tax, the innovation quality at the firm level measured by the number of patent citations is declining instead. (3) The spatial characteristics in the process of government $R \& D$ funding affecting innovation quality. Akcigit et al. [15] found that higher enterprise income tax triggers a shift in innovation activities' spatial location due to cross-state spillover effects. The study by Lu and Liu [16] is closely related to this paper. Lu and Liu [16], based on provincial panel data from 1997 to
2012, found that subsidies can enhance regional innovation quality.

Studies have begun to focus on the impact of government $\mathrm{R} \& \mathrm{D}$ funding on regional innovation quality, which inspires this study. Unfortunately, there are still some shortcomings in prior studies. (1) They lack a comprehensive examination of the basic connotation of innovation quality. Most previous studies focus on the impact of government $\mathrm{R} \& \mathrm{D}$ funding on innovation quantity [4, 7-10]. Few studies that focus on innovation quality only concentrate on its technological value and use the number of invention patents $[11,12]$ or the index system constructed based on patents [17] to measure it. However, innovation should satisfy market demand, and innovation quality should not only be reflected in its technological value (e.g., patents) but also in its economic value. (2) They neglect other innovation subjects within the regional innovation system. Most of the existing studies that focus on innovation quality analyze at the firm level, but the regional innovation system also includes other innovation subjects such as universities and research institutions. In the context of the growing importance of collaborative agglomeration of innovation by industry-university-research institutions [18], ignoring other innovation subjects' contribution is not conducive to examining the overall effect of government R\&D funding. (3) They ignore the spatial competitiveness and spatial heterogeneity in the process of government $R \& D$ funding affecting innovation quality. Although Akcigit et al. [15] argued that increased enterprise income tax causes a spatial location shift of innovation activities due to inter-regional spillover effects, they have not explored the underlying causes in depth. With the deepening of the innovationdriven development strategy, local governments' strategic interaction around $\mathrm{R} \& \mathrm{D}$ funding [19] may make government R\&D funding spatially competitive. Meanwhile, government $\mathrm{R} \& \mathrm{D}$ funding is a regional economic phenomenon in the Chinese context, so there is spatial competition for government R\&D funding between geographically adjacent regions and regions with little economic disparity. Besides, although Lu and Liu [16] argued that there might be spatial heterogeneity in the impact of subsidies on regional innovation quality, they have not discussed it deeply, either. There are differences in the marketization degree and innovation resources among regions, and thus, there may be differences in the need for government R\&D funding and its effectiveness in improving regional innovation quality. Ignorance of spatial heterogeneity may lead to bias in relevant studies.

Compared with existing studies, the main contributions of this study are reflected in the following aspects. (1) This study explores the connotation of regional innovation quality from technological, economic, and comprehensive aspects and then measures it from the above aspects. Thus, it provides new ideas for an in-depth exploration of the impact of government R\&D funding on regional innovation quality. (2) Based on the regional innovation system's perspective, this paper establishes a theoretical framework to analyze the impact of government $\mathrm{R} \& \mathrm{D}$ funding on regional innovation quality. Then, it uses this framework to examine the impact 
of government R\&D funding on direct innovation subjects (e.g., firms, universities, and research institutions) and indirect innovation subjects (e.g., financial institutions) within the regional innovation system. (3) Based on a spatial weight matrix obtained by nesting geographical and economic distances, this study examines the spatial competition of government R\&D funding to influence regional innovation quality and explores its mechanism. Also, it examines the spatial heterogeneity due to the location and administrative hierarchy of the city in the effect of government R\&D funding on regional innovation quality.

The rest of this study is organized as follows. Section 2 discusses the theoretical framework and proposes the research hypothesis; Section 3 describes the empirical framework; Section 4 reports and discusses the empirical results; Section 5 presents and discusses the results of the further analysis, and Section 6 contains the conclusions and implications.

\section{Theoretical Framework and Research Hypothesis}

2.1. Connotation and Measurement of Innovation Quality. In related studies, scholars have defined innovation quality from different perspectives. The main representative views are as follows. Firstly, in the technological aspect, innovation quality is equivalent to patent quality. The improvement of innovation quality implies technological progress and breakthroughs, which concentrate on the patent quality [11]. Given that only high-quality innovations can be patented [20], Chen et al. [1], Dang and Motohashi [12], and Tseng et al. [21] also focused on the technological value of innovation quality. They argued that innovation quality equals patent quality and then selected some patent-related indicators such as the number of invention patents and the breadth of patent knowledge to measure it. Secondly, in the economic aspect, innovation quality should be reflected in economic benefits. Although firms can develop plenty of innovation achievements, not each of them can produce economic value. Therefore, $\mathrm{He}$ [22] paid attention to the economic benefits brought by innovation, regarded the value of firms as the economic embodiment of innovation quality, and then selected Tobin $Q$ to measure it. Makkonen and Inkinen [23] focused on the market potential and market value of innovation quality. They argued that innovation prizes designed to stimulate new business activities could be used to measure it. Thirdly, in the integrated aspect, innovation quality should consider both the innovation quantity and innovation structure. Zheng et al. [17] also focused on the technological aspects of innovation quality. However, unlike previous scholars, they believed that innovation quality is comprehensive, including both the growth of innovation quantity and the optimization of innovation structure. Thus, they built an index system from the growth of patent quantity and the optimization of patent structure to measure innovation quality.

Based on the basic connotation of innovation quality and the fact that the traditional model of driving economic development by innovation quantity facing considerable resistance, it has been an objective requirement to improve innovation quality and drive high-quality development by high-quality innovation under the new economic normal. Thus, this study argues that innovation quality includes the technological value and the economic benefit of innovation, and it concerns both the quantity growth and the structure optimization of innovation.

2.2. Government R\&D Funding and Regional Innovation Quality. Great capital demand, high risk, and positive externalities make innovation activities vulnerable to market failure. Compared with low-quality innovation activities, high-quality innovation activities may face more severe market failures as they require more available capital, take higher risks, and undertake more significant externalities [24]. Arrow's theory [25] provides a theoretical rationale for using government $\mathrm{R} \& \mathrm{D}$ funding to alleviate the market failure in high-quality innovation activities. Based on it, some scholars have discussed the impact of government $\mathrm{R} \& \mathrm{D}$ funding on firm innovation activities from easing the constraint of innovation resources, sharing innovation risks, and correcting positive externalities of innovation achievements [24, 26]. However, in addition to firms, there are other direct innovation subjects (e.g., universities and research institutions that play the role of knowledge creators in the regional innovation system) and indirect innovation agents (e.g., financial institutions that provide financial support for direct innovation subjects) in the regional innovation system $[27,28]$. Therefore, considering the attributes of government R\&D funding and the attributes of different subjects within the regional innovation system, this study constructs a theoretical analysis framework for examining the impact of government $\mathrm{R} \& \mathrm{D}$ funding on regional innovation quality (Figure 1).

Firstly, government R\&D funding has resource attributes and is conducive to increasing the region's innovation resources of direct innovation subjects. It is because government $R \& D$ funding is an available innovation resource for direct regional subjects, which directly alleviate the shortage of innovation resources. Moreover, it assumes the cost of innovation activities through subsidies or tax preferences, thus sharing innovation risk [29]. In this situation, some direct subjects who worry about the future will invest more resources and bring in qualified talents to carry out innovation activities. Meanwhile, it can reduce the private costs of innovation activities [30] and increase their private benefit [31]. Therefore, government R\&D funding helps correct the innovation inertia caused by positive externalities, stimulate innovation subjects to invest more, and optimize the allocation of innovation resources, thus contributing to regional innovation quality.

Further, government $\mathrm{R} \& \mathrm{D}$ funding has signaling attributes that facilitate direct innovation subjects to obtain support from indirect innovation subjects such as financial institutions. The implementation of government $R \& D$ funding sends signals to indirect innovation subjects that the direct innovation subjects are recognized by the government $[32,33]$. It helps direct innovation subjects obtain long-term 


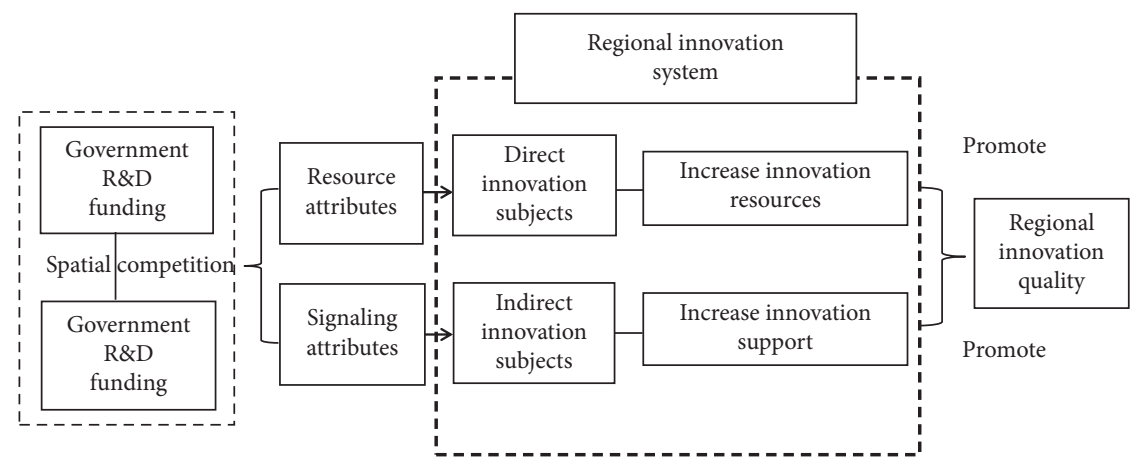

Figure 1: Framework of theoretical analysis.

financial support for innovation activities and enables innovation resources to be more and longer-lasting, and thus, it enhances the innovation quality in the region.

Finally, spatial competition exists in government R\&D funding, which is conducive to improving regional innovation quality. In the context of the fiscal decentralization system and the continuous promotion of innovative cities, local governments engage in a series of strategic competition around funding R\&D activities to develop the economy and innovation, which are eventually reflected in the continued expansion and increasing rigidity of fiscal expenditures on Science and Technology (S\&T) [19]. The competition around funding R\&D activities leads to an increase in innovation resources and innovation support, accelerates the flow of innovation resources, and strengthens the role of government $\mathrm{R} \& \mathrm{D}$ funding in improving regional innovation quality. Based on the above analysis, this study proposes the following hypothesis.

Hypothesis 1. Government R\&D funding can enhance regional innovation quality.

The resource attributes and signaling attributes of government R\&D funding make it conducive to improving regional innovation quality. However, subsidies and tax preferences have different characteristics, thus may have different effects on regional innovation quality. As an expost innovation compensation, tax preferences are hardly effective for innovation subjects with ex-ante financing difficulties or no tax obligations [26]. Thus, they may have a limited effect on improving regional innovation quality. In contrast, subsidies are ex-ante innovation support. They can promptly make up for the shortage of innovation resources, enhance the motivation of direct innovation subjects, and optimize the allocation of innovation resources by undertaking innovation funding in a timely manner. Therefore, subsidies may be more likely to enhance regional innovation quality. Based on the above analysis, this study proposes the following hypothesis.

Hypothesis 2. Of the two methods of government $\mathrm{R} \& \mathrm{D}$ funding (i.e., subsidies and tax preferences), subsidies may have a more significant effect on regional innovation quality.

\subsection{Heterogeneity Analysis of Government R\&D Funding Affecting Regional Innovation Quality}

2.3.1. Heterogeneity of the City Location. There are differences in the marketization process among the Eastern, Middle, and Western regions of China. The degree of marketization in the Eastern region is relatively higher than that in the Middle and Western region [34]. Thus, the market failure faced by the Eastern region in innovation activities is relatively minor. As the original purpose of government $\mathrm{R} \& \mathrm{D}$ funding is to alleviate the market failure in innovation activities, the degree of marketization will impact the effect of R\&D subsidies [17]. Relatively speaking, regions with a higher degree of marketization have lower information asymmetry, and direct innovation subjects can access financial support through financial institutions. Therefore, in these regions, the degree of market failure in innovation activities is lower [35], and there is less scope for government $\mathrm{R} \& \mathrm{D}$ funding to play a role. Thus, the effect on regional innovation quality may be relatively weak or even insignificant. However, the cities in the Middle and Western region are less market-oriented, with more severe market failures. The resource and signaling attributes of government $\mathrm{R} \& \mathrm{D}$ funding can be effectively leveraged, thus facilitating the regional innovation quality in these cities. Based on the above analysis, this study proposes the following hypothesis.

Hypothesis 3. Government R\&D funding is more likely to improve the regional innovation quality in Middle and Western cities with a lower marketization degree than that in Eastern cities with a higher marketization degree.

\subsubsection{Heterogeneity of the City Administrative Hierarchy.} Under China's current system, most of the elements, such as capital and talent, mainly distribute from the central government to local governments and from superior cities to subordinate cities [36]. Thus, cities with higher administrative hierarchy tend to have more advantages in accumulating innovation resources than those with ordinary administrative hierarchy. There is an optimal scale of government R\&D funding [16], and it may lead to an excessive accumulation of innovation resources within the region when exceeding a specific size. Influenced by the law of 
diminishing marginal returns, the efficiency of government R\&D funding will decrease as its size increases [37, 38], which may not be conducive to improving regional innovation quality. As a result, government R\&D funding has a limited and possibly negative impact on improving the innovation quality in higher-administrative-hierarchy cities with relatively adequate innovation resources. In contrast, as additional resources, it can effectively alleviate the lack of innovation resources faced by general-administrative-hierarchy cities. Based on the above analysis, this study proposes the following hypothesis.

Hypothesis 4. Government R\&D funding is more likely to improve the regional innovation quality in general-administrative-hierarchy cities with fewer innovation resources than higher-administrative-hierarchy cities with more abundant innovation resources.

\section{Empirical Framework}

3.1. Model. This study establishes a basic model to test the impact of government R\&D funding on regional innovation quality. The model, with regional innovation quality as the dependent variable and subsidies and tax preferences as the independent variables, is set as follows: innovation $_{i t}=\alpha l_{n}+\beta_{1}$ subsidy $_{i t}+\beta_{2} \operatorname{tax}_{i t}+\beta_{3} Z_{i t}+\varepsilon_{i t}$.

In equation (1), innovation denotes regional innovation quality, subsidy and tax denote subsidies and tax preferences, respectively, $i$ and $t$ denote the number of cross sections and the number of periods, $\alpha$ is a constant term, $l_{n}$ is an $N \times 1$ order unit vector, $Z$ are control variables representing other factors that may affect regional innovation quality, $\varepsilon$ is a random perturbation term, and $\beta_{1}, \beta_{2}$, and $\beta_{3}$ are the estimated coefficients of each parameter.

The spillover effect of innovation activities may make regional innovation quality spatially correlated. Simultaneously, competition for government R\&D funding carried by regions may make government R\&D funding spatially correlated across regions. In this case, nonspatial econometrics models that assume that regions are independent of each other fail to account for the spatial correlation of regional innovation quality and government R\&D funding, which may bias the results. Therefore, based on equation (1), the spatial Durbin model (SDM) is established by introducing the spatial interaction terms of regional innovation quality, subsidies and tax preferences, and control variables, as shown in the following equation:

$$
\begin{aligned}
\text { innovation }_{i t}= & \alpha l_{n}+\beta_{1} \text { subsidy }_{i t}+\beta_{2} \operatorname{tax}_{i t}+\beta_{3} Z_{i t}+\theta_{1} W \times \text { subsidy }_{i t} \\
& +\theta_{2} W \times \operatorname{tax}_{i t}+\theta_{3} W \times Z_{i t}+\rho W \times \text { innovation }_{i t}+\varepsilon_{i t},
\end{aligned}
$$

where innovation denotes regional innovation quality, subsidy and tax denote subsidies and tax preferences, respectively, $i$ and $t$ denote the number of cross sections and the number of periods, $\alpha$ is a constant term, $l_{n}$ is an $N \times 1$ order unit vector, $\mathrm{Z}$ are control variables representing other factors that may affect the regional innovation quality, $\varepsilon$ is a random perturbation term, $\beta_{1}, \beta_{2}$, and $\beta_{3}$ are the estimated coefficients of each parameter, representing the influence of local independent and control variables on local innovation quality, $\theta_{1}, \theta_{2}$, and $\theta_{3}$ are the spatial correlation coefficients, representing the influence of local independent and control variables on the innovation quality of neighboring regions, $\rho$ is the spatial autocorrelation coefficient, representing the influence of local innovation quality on the innovation quality of neighboring regions, and $W$ is a spatial weight matrix.

\subsection{Description of Variables}

3.2.1. Dependent Variable: Regional Innovation Quality. This study constructs an evaluation index system of regional innovation quality containing technological, economic, and comprehensive indicators to measure regional innovation quality. Compared with previous studies that measure it by indicators with a single dimension $[11,12]$ or an index system constructed from a single dimension [21], this approach may be more objective and accurate.
Table 1 shows the evaluation index system of regional innovation quality. The first-level index is composed of the technological and economic aspects of innovation quality. The second-level index reflects the comprehensive aspect of it, which measures the technological and economic aspects of innovation quality from the quantitative and structural dimensions, respectively. Moreover, the number of granted patents for invention and the proportion of granted patents for invention reflect the technological aspect of innovation quality in quantitative and structural terms, respectively. The firm profits and average asset margins reflect the economic aspect of innovation quality in quantitative and structural terms, respectively.

Note that the proportion of granted patents for the invention is calculated by dividing the number of granted patents for the invention by the total number of granted patents. The main reason for selecting the number of invention patents instead of other types is that, under China's current patent law, patent applications for inventions are usually subject to a rigorous substantive examination, with a higher requirement for novelty and, therefore, more innovative [12]. Besides, the reason for selecting the number of granted patents rather than applied ones is that patent applications are not always granted, and granted parents tend to be of higher quality than ungranted ones [39].

Additionally, the firm profits are the ones of industrial enterprises above the state-designated scale. The average 
TABLE 1: Evaluation index system of regional innovation quality.

\begin{tabular}{lcc}
\hline First-level index & Second-level index & Unit \\
\hline Technological aspect of innovation quality & $\begin{array}{c}\text { Number of patents granted for the invention } \\
\text { Proportion of patents granted for the invention }\end{array}$ & $\begin{array}{c}\text { Piece } \\
\%\end{array}$ \\
\hline Economic aspect of innovation quality & Average asset margins & $\begin{array}{c}10000 \text { yuan } \\
\%\end{array}$ \\
\hline
\end{tabular}

asset margins are calculated by dividing the firm profits by their average annual total assets. The reasons for choosing firm profits and their share of average total assets to measure the economic aspect of innovation quality are as follows. On the one hand, they are common indicators to measure the economic value of firms [40], and profit maximization is in line with the economic objective of firms to improve the quality of innovation. On the other hand, as industry-university-research cooperation becomes closer, the profits of firms in the region include, to a certain extent, the economic contributions generated by universities, research institutes, and firms in collaborative innovation.

After constructing the index system, it is critical to select an appropriate method to calculate the multiple indicators. In related studies, Fan et al. [41], [42] evaluated regional innovation efficiency from the perspectives of innovation input and innovation output using the improved Data Envelopment Analysis (DEA) model and the Slack-Based Measure (SBM) model, respectively. Moreover, Yang et al. [43] evaluated patent quality from six dimensions using the Principal Component Analysis (PCA) method. However, compared with regional innovation efficiency, regional innovation quality is more concerned with the technological and economic value of innovation rather than the efficiency of converting innovation input into innovation output. Therefore, the DEA model and the SBM model, which are more suitable for evaluating efficiency [41], may not be suitable for this study. And, the PCA method, as a method of dimensionality reduction analysis, is more suitable for evaluating index systems containing a large number of indicators. However, the regional innovation quality index system constructed in this paper contains fewer indicators. Therefore, this study adopts the Global Entropy Value (GEV) method [44] to assign weights to the evaluation index system of regional innovation quality. The GEV method is an objective assignment method based on the change of the data itself, which can retain the information of all indicators and is relatively accurate.

Assume that there are $P$ evaluation indicators and that the regional innovation quality of $n$ cities in Tyears needs to be evaluated (there are a total of $n T$ evaluation subjects). Meantime, the matrix $X_{i j}(i=1,2, \ldots, n T ; j=1,2, \ldots, p)$ represents the $j$ th indicator of the $i$ th evaluation object. The main steps for assigning weights using the GEV method are as follows:

Step 1. Standardize the matrix:

$$
Y_{i j}=\frac{X_{i j}-\min \left(X_{i j}\right)}{\max \left(X_{i j}\right)-\min \left(X_{i j}\right)} .
$$

Note that $Y_{i j}$ is the matrix element after normalization.

Step 2. Calculate the entropy value of the $j$ th index:

$$
E_{j}=-\frac{1}{\ln (n T)} \sum_{i=1}^{n T} p_{i j} \times \ln \left(p_{i j}\right)
$$

where $p_{i j}=-\left(Y_{i j} / \sum_{i=1}^{n T} Y_{i j}\right)$.

Step 3. Calculate the redundancy of the entropy:

$$
D_{j}=1-E_{j} \text {. }
$$

Step 4. Calculate the weight of each index:

$$
W_{j}=-\frac{D_{j}}{\sum_{j=1}^{p} D_{j}} .
$$

Step 5. Calculate the composite evaluation index of the regional innovation quality:

$$
C_{i j}=\sum_{j=1}^{p} W_{j} \times Y_{i j}
$$

3.2.2. Independent Variable: Government R\&D Funding. This study considers two primary forms of government R\&D funding, namely, subsidies and tax preferences.

(1) Subsidies (Subsidy). The share of fiscal expenditure on S\&T in each region's GDP is selected to measure subsidies in the benchmark regression (this paper uses GDP to remove the effect of regional size factors on the estimated results when constructing measurements of government R\&D funding). Fiscal expenditure on S\&T is a common indicator of government $\mathrm{R} \& \mathrm{D}$ funding at the city level [19]. It refers to the expenditure on basic research, applied research, technology research and development, S\&T management affairs, S\&T popularization, S\&T cooperation, etc. It can increase innovation resources directly and attract indirect innovation subjects to increase their innovation support by sending a signal, thus improving regional innovation quality. Besides, referring to $\mathrm{Wu}$ and Deng [45] and Zhang and Huang [46], this study re-measures subsidies in two ways (i.e., fiscal S\&T expenditure and its share of total fiscal expenditure) to perform robustness tests. The former is named the size of subsidies, and the 
latter is called the intensity of subsidies to facilitate the distinction.

(2) Tax Preferences (Tax). As for the tax preferences, this paper selects the share of enterprise income tax of each region's fiscal revenue in GDP to measure them in the benchmark regression. Currently, China's tax preferences' policies for innovation activities mainly include accelerated depreciation of assets, deductions for R\&D expenses, and preferential tax rates for high-tech firms. These will ultimately be reflected in the enterprise income tax paid by firms [47], that is, the lower the enterprise income tax, to some extent, the stronger the tax preferences. It should be noted that this study re-measures the tax preferences in two ways (i.e., enterprise income tax and its share of total fiscal revenue) to perform robustness tests. The former is named the size of tax preferences, and the latter is called the intensity of tax preferences to facilitate the distinction.

3.2.3. Control Variables. The following control variables are selected to control for the possible influence of other variables on regional innovation quality:

(1) Innovation Resources (Resources). The improvement of innovation quality is inseparable from the input of innovation resources, including innovation funds and innovation personnel. However, this study concentrates on innovation personnel mainly for the reasons below. Firstly, as the carrier of knowledge, the importance of innovation personnel in regional innovation activities is becoming increasingly prominent in today's knowledge economy. Highquality innovation activities cannot be achieved without the intellectual support of innovators. Another reason for it is the lack of statistics on R\&D funds at the city level in China. After extensively consulting statistical information such as the China City Statistical Yearbook and the China Regional Economic Statistical Yearbook, we have not obtained statistical information on R\&D funds or personnel based on the same statistical caliber. Therefore, with reference to $\mathrm{Lu}$ and Wang [48], the number of employees in scientific research and technological services is selected to measure innovation resources.

(2) Innovation Support (Support). In the regional innovation system, there are also indirect innovation subjects besides direct innovation subjects. The improvement of regional innovation quality requires not only the efforts of direct innovation subjects but also the innovation support from indirect innovation subjects, especially the financial support from banks in the situation where direct innovation subjects are generally facing financing constraints [49]. In the Chinese context, financing from banks is common for direct innovation subjects to obtain financial innovation support due to the difficulty in financing through capital markets [50].
(3) Economic Development Level (Economy). The level of economic development reflects the economic strength in each region. Generally speaking, the stronger the economy, the stronger the innovation. This study selects the per capita GDP to measure the economic development level.

(4) Industrial Structure Upgrading (Industry). The spatial reallocation of resources, competition, and synergies arising from the process of industrial upgrading can have an impact on innovation [51]. The proportion of tertiary industry employees in total employees is selected to measure the upgrading of industrial structure.

(5) Firm Size (Size). Some scholars argue that the larger the firm, the greater its innovation [52]. Others argue that larger is not better, and small-scale firms account for a higher share of R\&D outcomes instead [53]. This study selects the value of total assets of industrial enterprises above the state-designated scale divided by the number of firms to measure the firm size.

(6) Infrastructure Level (Infrastructure). A well-developed infrastructure can facilitate the communication of information and the exchange of knowledge [54], which are beneficial to regional innovation quality. The combined value of postal and telecommunications services as a share of GDP is selected to measure the infrastructure level.

(7) Opening-Up Degree (Opening). In an open economy, a country can improve innovation quality by optimizing the allocation of innovation resources through various channels, such as foreign direct investment (FDI) and exports. In this study, the combined value of FDI and exports as a share of GDP is chosen to measure the opening-up degree.

(8) Institutional Environment (Institution). The institutional environment is a crucial component of the regional innovation environment. The clear function of the government and market and the development of the nonstate economy are conducive to stimulating innovation [55]. This study chooses total assets of state-owned and state-controlled firms as a proportion of all firms in the province where the city is located as the proxy indicator. Note that a smaller value indicates a better institutional environment in this study.

(9) Education Level (Education). Education helps develop the talent needed for innovation, and hence, the education level is an essential factor in innovation [56]. The number of students enrolled in higher education institutions is selected to measure the education level.

3.2.4. Spatial Weight Matrix. The first law of geography states that geographic proximity makes things more closely related. Geographic proximity creates favorable conditions for mutual learning, competition, and imitation of 
government R\&D funding policies [19], as well as the spillover effect of innovation activities [57]. Meanwhile, economic disparity also influences government $\mathrm{R} \& \mathrm{D}$ funding and regional innovation quality. It is because, on the one hand, regions with small economic disparity tend to have closer assessment targets and pressures. In this situation, the interactions of the local government around $R \& D$ funding are more intense. On the other hand, these regions tend to have closer innovation strength, which is more conducive to acquiring and absorbing appropriate technologies and further improving regional innovation quality. Therefore, this study constructs a nested spatial weight matrix of geographic distance and economic distance to depict the spatial correlation of government R\&D funding and regional innovation quality. The specific form is as follows:

$$
W_{1}= \begin{cases}\frac{1}{|d|} \times \frac{1}{\left|\mathrm{GDP}_{i}-\mathrm{GDP}_{j}\right|}, & i \neq j, \\ 0, & i=j,\end{cases}
$$

where $i$ and $j$ denote regions $i$ and $j$, respectively, $d$ is the spherical distance between the two regions, and GDP is the average annual GDP per capita for each region during the study period.

\subsection{Instructions of Data Processing and Results of Descriptive} Statistical Analysis. This study takes the panel data in 283 Chinese cities from 2011 to 2017 as the research sample. The original patent data is from the China Research Data Service Platform (CNRDS). The original data of direct subsidies and tax preferences are from "S\&T Expenditure" and "Enterprise Income Tax" in the China Urban Statistical Yearbook and China Regional Economic Statistical Yearbook. Meanwhile, other related data are mainly derived from the China Urban Statistical Yearbook and China Regional Economic Statistical Yearbook. Moreover, in this study, the following cities are excluded from the sample: (1) cities undergoing administrative adjustments, such as Chaohu; (2) municipalities directly under the central government with special status, such as Beijing, Tianjin, Shanghai, and Chongqing; (3) cities with seriously missing data, such as Taiwan, Hong Kong, Macao, and some Western cities. As for the few missing data, this study completes it by looking up statistical yearbooks as well as statistical bulletins on national economic and social development for each city.

It should be noted that the processing of the original data is as follows. First, the data such as exports and FDI are converted into the unit of 10000 yuan based on the average exchange rate of the US dollar to the RMB for the corresponding year. Second, the variables involving the amount of money, such as GDP and exports, are converted into comparable prices with 2011 as the base period using the GDP deflator. Besides, this study uses Stata15 to calculate spatial weight matrix and Moran's index (Moran's $I$ ) and uses MATLAB R2016b to estimate models and perform corresponding tests. Table 2 reports the results of descriptive statistics.

\section{Empirical Results and Discussion}

4.1. Spatial Correlation Tests on Regional Innovation Quality. After using the GEV method to assign weights to the evaluation index system of regional innovation quality and calculate the scores of it, this study uses Moran's index (Moran's $I$ ) to determine whether there is a spatial correlation between regional innovation quality. Moran's $I$ is calculated by the following equation:

$$
\operatorname{Morans}^{\prime} I=\frac{n \sum_{i} \sum_{j} W_{i j}\left(x_{i}-\bar{x}\right)\left(x_{j}-\bar{x}\right)}{\sum_{i} \sum_{j} W_{i j} \sum_{i=1}\left(x_{i}-\bar{x}\right)^{2}}=\frac{\sum_{i=1}^{n} \sum_{j=1}^{n} W_{i j}\left(x_{i}-\bar{x}\right) x_{j}-\bar{x}}{S^{2} \sum_{i=1}^{n} \sum_{j=1}^{n} W_{i j}},
$$

where $S^{2}=(1 / n) \sum_{i=1}^{n}\left(x_{i}-\bar{x}\right)^{2}, \bar{x}=(1 / n) \sum_{i=1}^{n} x_{i}, x_{i}$ denotes the observation of region $i, n$ is the sample size, and $W_{i j}$ is the element of the spatial weight matrix. The value of Moran's $I$ is between -1 and 1 , with values greater than 0 indicating a strong positive spatial correlation and values less than 0 indicating a strong negative spatial correlation. Table 3 reports the results of Moran's I test for regional innovation quality.

The results in Table 3 show that Moran's $I$ of regional innovation quality from 2011 to 2017 all pass the test at the $1 \%$ significance level, indicating a positive spatial correlation of regional innovation quality: the higher the quality of local innovation, the higher the quality of innovation in neighboring regions. It is necessary and reasonable to take the spatial correlation of regional innovation quality into consideration. Besides, Moran's I of regional innovation quality shows an increasing trend year by year, indicating that, with the increasing of inter-regional exchanges and linkages, the spillover effect of regional innovation quality is gradually enhanced, and hence, the spatial correlation of it is strengthened.

4.2. Basic Regression. In this study, the maximum likelihood method (MLE) is used to estimate the model [58], and the tests are carried out according to the lines proposed by Elhorst [59]. The test results of LM statistics and robust LM statistics show that the spatial Durbin model (SDM) should be established in this study. Meanwhile, the Wald test rejects the original hypothesis that the SDM should degenerate into a spatial lag model (SLM) or a spatial error model (SEM), which further confirms that the SDM is suitable for this study. In fact, SDM can take the spatial correlation of the dependent and independent variables into account 
TABLe 2: Results of descriptive statistics $(N=1981)$.

\begin{tabular}{|c|c|c|c|c|c|c|c|}
\hline Variables & Calculation methods & $\begin{array}{c}\text { Expected } \\
\text { symbol }\end{array}$ & Mean & SD & Min & Max & Unit \\
\hline $\begin{array}{l}\text { Regional innovation } \\
\text { quality (Innovation) }\end{array}$ & According to the global entropy method & - & 0.051 & 0.066 & 0.007 & 0.828 & - \\
\hline Subsidies (Subsidy) & S\&T expenditure/GDP & + & 0.006 & 0.004 & 0.001 & 0.030 & $\%$ \\
\hline Tax preferences (Tax) & Enterprise income tax revenue/GDP & - & 0.003 & 0.003 & 0 & 0.063 & $\%$ \\
\hline $\begin{array}{l}\text { Innovation resources } \\
\text { (Resources) }\end{array}$ & $\begin{array}{c}\text { Number of employees in scientific research and } \\
\text { technological services }\end{array}$ & + & 9730 & 18178 & 200 & 179665 & Person \\
\hline $\begin{array}{l}\text { Innovation support } \\
\text { (Support) }\end{array}$ & Loan balances of banking institutions/GDP & + & 0.916 & 0.565 & 0.118 & 7.450 & $\%$ \\
\hline $\begin{array}{l}\text { Economic development } \\
\text { level (Economy) }\end{array}$ & GDP per capita & + & 38891 & 26152 & 6457 & 402457 & $\begin{array}{l}10000 \\
\text { yuan }\end{array}$ \\
\hline $\begin{array}{l}\text { Industrial structure } \\
\text { upgrading (Industry) }\end{array}$ & $\begin{array}{c}\text { Employees in the tertiary sector in urban units/ } \\
\text { total number of employees }\end{array}$ & + & 0.518 & 0.132 & 0.154 & 0.948 & $\%$ \\
\hline Firm size (Size) & $\begin{array}{l}\text { Total assets of industrial enterprises above the } \\
\text { state-designated scale/number of them }\end{array}$ & + or - & 22915 & 28258 & 1135 & 335259 & $\begin{array}{c}10000 \\
\text { yuan/each }\end{array}$ \\
\hline $\begin{array}{l}\text { Infrastructure level } \\
\text { (Infrastructure) }\end{array}$ & $\begin{array}{l}\text { Combined value of postal and } \\
\text { telecommunications services/GDP }\end{array}$ & + & 0.018 & 0.011 & 0.002 & 0.205 & $\%$ \\
\hline $\begin{array}{l}\text { Opening-up degree } \\
\text { (Opening) }\end{array}$ & Combined value of the FDI and exports/GDP & + & 0.130 & 0.270 & 0 & 6.625 & $\%$ \\
\hline $\begin{array}{l}\text { Institutional } \\
\text { environment } \\
\text { (Institution) }\end{array}$ & $\begin{array}{l}\text { Total assets of state-owned and state-controlled } \\
\text { firms in the province/total assets of all firms }\end{array}$ & - & 0.361 & 0.156 & 0.108 & 0.827 & $\%$ \\
\hline $\begin{array}{l}\text { Education level } \\
\text { (Education) }\end{array}$ & Number of students in higher education & + & 84216 & 152627 & 0 & 1067335 & Person \\
\hline
\end{tabular}

Note. The above variables are all logarithmically treated in the following regressions.

TABLE 3: Results of Moran's I test for the regional innovation quality.

\begin{tabular}{lccccccc}
\hline Year & 2011 & 2012 & 2013 & 2014 & 2015 & 2016 & 2017 \\
\hline \multirow{2}{*}{ Moran's $I$} & $0.2310^{* * *}$ & $0.2760^{* * *}$ & $0.2980^{* * *}$ & $0.3120^{* * *}$ & $0.3390^{* * *}$ & $0.3720^{* * *}$ & $0.3680^{* * *}$ \\
& $(7.6680)$ & $(9.1470)$ & $(9.8530)$ & $(10.3120)$ & $(11.1800)$ & $(12.2560)$ & $(12.1490)$ \\
\hline
\end{tabular}

Note. ${ }^{* * *},{ }^{* *}$, and ${ }^{*}$ denote a significance level of $1 \%, 5 \%$, and $10 \%$, respectively. The $z$-statistic is in parentheses.

simultaneously, which just meets the research need of this study. Although the Hausman test shows that the fixed effects are better than the random effect, to enhance the reliability of the results, this study reports the estimated results of SDM in five estimation forms, as shown in Table 4. From left to right, the estimates are for no fixed effect (nonF), spatial fixed effect $(\mathrm{sF})$, time fixed effect $(\mathrm{tF})$, time and spatial fixed effect (stF), and random effect $(r)$.

The results in Table 4 show that $\bar{R}^{2}$ is high in the results of the five estimation forms, indicating that the SDM is a better fit overall and can better reflect the impact of government $\mathrm{R} \& \mathrm{D}$ funding on regional innovation quality when considering spatial correlation. This study focuses on stF when analyzing the estimation results. Because the strength of government $\mathrm{R} \& \mathrm{D}$ funding may vary over time and space, its impact on regional innovation quality may also vary. In the form of stF, the effects of time- and space-varying factors on the steady state can be observed simultaneously [60], which meets this paper's research need.

The stF estimated results show that regional innovation quality is not only influenced by factors such as subsidies and economic development level in the region but also by the innovation quality in neighboring regions. The spatial autocorrelation coefficient is positive and passes the test at the
$1 \%$ significance level, further indicating a positive spatial correlation in regional innovation quality. The reason may be that the geographical proximity and the narrowing of the economic gap create convenient conditions for the flow of innovation resources. Meanwhile, the spillover effect of regional innovation quality also enables a region to learn from and imitate neighboring regions with high-quality innovation to improve their innovation quality.

In terms of the effect of subsidies, they passed the test at the $5 \%$ level in all five estimation forms, indicating that subsidies contribute significantly to regional innovation quality. Thus, Hypothesis 1 is partially confirmed. By meeting the financial need for high-quality innovation activities, sharing risks, and correcting positive externalities, subsidies compensate for market failures and stimulate the high-quality innovation effectively, thus contributing to the improvement of regional innovation quality. However, the result is inconsistent with Dang and Motohashi [12], who found that subsidies cannot improve China's innovation quality. The possible reason may be that they focused on the subsidies for the patent application, approval fees, and patent awards, but incentivizing patents is not the only purpose of government R\&D funding. Moreover, in contrast to their study, this study considers both the technological, 
TABLe 4: Results of the spatial Durbin model (SDM).

\begin{tabular}{|c|c|c|c|c|c|}
\hline & nonf & $\mathrm{sF}$ & $\mathrm{tF}$ & $\mathrm{stF}$ & $r$ \\
\hline Intercept & $\begin{array}{c}-5.0825^{* * *} \\
(-6.8209)\end{array}$ & - & - & - & - \\
\hline Subsidy & $\begin{array}{c}0.0954^{* * *} \\
(5.5844)\end{array}$ & $\begin{array}{c}0.1140^{* * *} \\
(6.2473) \\
\end{array}$ & $\begin{array}{c}0.1017^{* * *} \\
(5.9513)\end{array}$ & $\begin{array}{c}0.1203^{* * *} \\
(7.1503)\end{array}$ & $\begin{array}{c}0.1021^{* * *} \\
(5.9862)\end{array}$ \\
\hline Tax & $\begin{array}{c}0.0251 \\
(0.9754) \\
\end{array}$ & $\begin{array}{c}0.0269 \\
(0.9698)\end{array}$ & $\begin{array}{c}0.0177 \\
(0.6930)\end{array}$ & $\begin{array}{c}0.0201 \\
(0.7888)\end{array}$ & $\begin{array}{c}0.0177 \\
(0.6949)\end{array}$ \\
\hline Resources & $\begin{array}{l}0.2692^{* * *} \\
(18.4879)\end{array}$ & $\begin{array}{l}0.2514^{* * *} \\
(15.6939)\end{array}$ & $\begin{array}{l}0.2695^{* * *} \\
(18.5306)\end{array}$ & $\begin{array}{l}0.2517^{* * *} \\
(17.0355)\end{array}$ & $\begin{array}{l}0.2691^{* * *} \\
(18.5299)\end{array}$ \\
\hline Support & $\begin{array}{c}0.1563^{* * *} \\
(5.4227) \\
\end{array}$ & $\begin{array}{c}0.1777^{* * *} \\
(5.6715) \\
\end{array}$ & $\begin{array}{c}0.1583^{* * *} \\
(5.5116) \\
\end{array}$ & $\begin{array}{c}0.1812^{* * *} \\
(6.2941) \\
\end{array}$ & $\begin{array}{c}0.1588^{* * *} \\
(5.5380) \\
\end{array}$ \\
\hline Economy & $\begin{array}{l}0.3599^{* * *} \\
(12.4953) \\
\end{array}$ & $\begin{array}{c}0.3773^{* * *} \\
(12.1791) \\
\end{array}$ & $\begin{array}{c}0.3707^{* * *} \\
(12.9481) \\
\end{array}$ & $\begin{array}{c}0.3883^{* * *} \\
(13.6717) \\
\end{array}$ & $\begin{array}{l}0.3711^{* * *} \\
(12.9835) \\
\end{array}$ \\
\hline Industry & $\begin{array}{l}0.1047^{* *} \\
(2.3695)\end{array}$ & $\begin{array}{l}0.0905^{*} \\
(1.8962)\end{array}$ & $\begin{array}{l}0.1113^{* *} \\
(2.5208)\end{array}$ & $\begin{array}{c}0.0963^{* *} \\
(2.1889) \\
\end{array}$ & $\begin{array}{l}0.1110^{* *} \\
(2.5192)\end{array}$ \\
\hline Size & $\begin{array}{c}0.0094 \\
(0.4830) \\
\end{array}$ & $\begin{array}{c}0.0009 \\
(0.0445) \\
\end{array}$ & $\begin{array}{c}0.0035 \\
(0.1847) \\
\end{array}$ & $\begin{array}{c}-0.0066 \\
(-0.3493) \\
\end{array}$ & $\begin{array}{c}0.0034 \\
(0.1754) \\
\end{array}$ \\
\hline Infrastructure & $\begin{array}{c}-0.0137 \\
(-0.5992) \\
\end{array}$ & $\begin{array}{c}-0.0124 \\
(-0.5090) \\
\end{array}$ & $\begin{array}{c}-0.0068 \\
(-0.2975) \\
\end{array}$ & $\begin{array}{c}-0.0061 \\
(-0.2657) \\
\end{array}$ & $\begin{array}{c}-0.0068 \\
(-0.2981)\end{array}$ \\
\hline Opening & $\begin{array}{r}0.0354^{* * *} \\
(3.3336) \\
\end{array}$ & $\begin{array}{r}0.0355^{* * *} \\
(3.1014) \\
\end{array}$ & $\begin{array}{r}0.0380^{* * * *} \\
(3.5948) \\
\end{array}$ & $\begin{array}{r}0.0382^{* * *} \\
(3.6285) \\
\end{array}$ & $\begin{array}{r}0.0380^{* * * *} \\
(3.6028) \\
\end{array}$ \\
\hline Institution & $\begin{array}{c}-0.1738^{* * *} \\
(-5.2167)\end{array}$ & $\begin{array}{c}-0.2044^{* * *} \\
(-5.6802) \\
\end{array}$ & $\begin{array}{c}-0.1665^{* * *} \\
(-5.0181)\end{array}$ & $\begin{array}{c}-0.1953^{* * *} \\
(-5.9102) \\
\end{array}$ & $\begin{array}{c}-0.1671^{* * *} \\
(-5.0448) \\
\end{array}$ \\
\hline Education & $\begin{array}{c}0.0389^{* * *} \\
(3.5618) \\
\end{array}$ & $\begin{array}{c}0.0427^{* * *} \\
(3.6654) \\
\end{array}$ & $\begin{array}{c}0.0377^{* * *} \\
(3.4681) \\
\end{array}$ & $\begin{array}{c}0.0410^{* * *} \\
(3.8313) \\
\end{array}$ & $\begin{array}{c}0.0378^{* * *} \\
(3.4820) \\
\end{array}$ \\
\hline $\mathrm{W}^{*}$ Subsidy & $\begin{array}{c}-0.0022 \\
(-0.0643)\end{array}$ & $\begin{array}{c}-0.0071 \\
(-0.1971) \\
\end{array}$ & $\begin{array}{c}0.0571 \\
(1.3762) \\
\end{array}$ & $\begin{array}{c}0.0629 \\
(1.5407)\end{array}$ & $\begin{array}{c}0.0571 \\
(1.3805) \\
\end{array}$ \\
\hline $\mathrm{W}^{*} \operatorname{Tax}$ & $\begin{array}{c}-0.0092 \\
(-0.1865) \\
\end{array}$ & $\begin{array}{c}0.0198 \\
(0.3838) \\
\end{array}$ & $\begin{array}{c}-0.0722 \\
(-1.1218)\end{array}$ & $\begin{array}{c}-0.0225 \\
(-0.3558) \\
\end{array}$ & $\begin{array}{c}-0.0711 \\
(-1.1067)\end{array}$ \\
\hline $\mathrm{W}^{*}$ Resources & $\begin{array}{c}-0.0416 \\
(-1.0647) \\
\end{array}$ & $\begin{array}{c}-0.0461 \\
(-1.0842) \\
\end{array}$ & $\begin{array}{c}-0.0198 \\
(-0.4582) \\
\end{array}$ & $\begin{array}{c}-0.0237 \\
(-0.5288) \\
\end{array}$ & $\begin{array}{c}-0.0199 \\
(-0.4608)\end{array}$ \\
\hline $\mathrm{W}^{*}$ Support & $\begin{array}{l}-0.1333^{* *} \\
(-2.3394) \\
\end{array}$ & $\begin{array}{c}-0.1764^{* * *} \\
(-2.9224) \\
\end{array}$ & $\begin{array}{c}-0.0555 \\
(-0.8099)\end{array}$ & $\begin{array}{c}-0.0759 \\
(-1.1146)\end{array}$ & $\begin{array}{c}-0.0561 \\
(-0.8207)\end{array}$ \\
\hline $\mathrm{W}^{*}$ Economy & $\begin{array}{c}-0.2512^{* * *} \\
(-3.8297) \\
\end{array}$ & $\begin{array}{c}-0.2782^{* * *} \\
(-3.9802) \\
\end{array}$ & $\begin{array}{c}-0.0558 \\
(-0.7775) \\
\end{array}$ & $\begin{array}{c}-0.0535 \\
(-0.7534) \\
\end{array}$ & $\begin{array}{c}-0.0561 \\
(-0.7824) \\
\end{array}$ \\
\hline $\mathrm{W}^{*}$ Industry & $\begin{array}{c}0.0265 \\
(0.2657) \\
\end{array}$ & $\begin{array}{c}0.0155 \\
(0.1456) \\
\end{array}$ & $\begin{array}{c}0.0699 \\
(0.6176) \\
\end{array}$ & $\begin{array}{c}0.0263 \\
(0.2302) \\
\end{array}$ & $\begin{array}{c}0.0693 \\
(0.6130) \\
\end{array}$ \\
\hline $\mathrm{W}^{*}$ Size & $\begin{array}{c}0.0052 \\
(0.1309) \\
\end{array}$ & $\begin{array}{c}0.0404 \\
(0.9789) \\
\end{array}$ & $\begin{array}{c}-0.0717 \\
(-1.4893) \\
\end{array}$ & $\begin{array}{c}-0.0703 \\
(-1.4740) \\
\end{array}$ & $\begin{array}{c}-0.0716 \\
(-1.4883) \\
\end{array}$ \\
\hline $\mathrm{W}^{*}$ Infrastructure & $\begin{array}{c}-0.0049 \\
(-0.0943) \\
\end{array}$ & $\begin{array}{c}0.0202 \\
(0.3561) \\
\end{array}$ & $\begin{array}{c}0.0638 \\
(1.0775) \\
\end{array}$ & $\begin{array}{c}0.0792 \\
(1.3486) \\
\end{array}$ & $\begin{array}{c}0.0641 \\
(1.0831) \\
\end{array}$ \\
\hline $\mathrm{W}^{*}$ Opening & $\begin{array}{c}0.0001 \\
(0.0054) \\
\end{array}$ & $\begin{array}{c}-0.0088 \\
(-0.3283) \\
\end{array}$ & $\begin{array}{c}0.0197 \\
(0.7567) \\
\end{array}$ & $\begin{array}{c}0.0156 \\
(0.6008) \\
\end{array}$ & $\begin{array}{c}0.0197 \\
(0.7581)\end{array}$ \\
\hline $\mathrm{W}^{*}$ Institution & $\begin{array}{c}0.1064 \\
(1.5362)\end{array}$ & $\begin{array}{c}0.1049 \\
(1.4188)\end{array}$ & $\begin{array}{c}0.2033^{* * *} \\
(2.6974)\end{array}$ & $\begin{array}{l}0.1921^{* *} \\
(2.5748)\end{array}$ & $\begin{array}{c}0.2033^{* * *} \\
(2.7027)\end{array}$ \\
\hline $\mathrm{W}^{*}$ Education & $\begin{array}{c}-0.0184 \\
(-0.6899)\end{array}$ & $\begin{array}{c}-0.0271 \\
(-0.9509)\end{array}$ & $\begin{array}{c}-0.0271 \\
(-0.8693)\end{array}$ & $\begin{array}{c}-0.0384 \\
(-1.2300)\end{array}$ & $\begin{array}{c}-0.0273 \\
(-0.8777)\end{array}$ \\
\hline $\mathrm{W}^{*}$ Innovation & $\begin{array}{c}0.2779^{* * *} \\
(7.1066)\end{array}$ & $\begin{array}{c}0.2969^{* * *} \\
(7.6701) \\
\end{array}$ & $\begin{array}{c}0.1959^{* * *} \\
(4.8506) \\
\end{array}$ & $\begin{array}{c}0.1869^{* * *} \\
(4.6176) \\
\end{array}$ & $\begin{array}{c}0.1959^{* * *} \\
(4.8508) \\
\end{array}$ \\
\hline Theta & - & - & - & - & $\begin{array}{l}0.9875^{* * *} \\
(21.9099) \\
\end{array}$ \\
\hline$\delta^{2}$ & 0.1688 & 0.1679 & 0.1662 & 0.1406 & 0.1651 \\
\hline$\overline{R^{2}}$ & 0.6408 & 0.6561 & 0.6431 & 0.6603 & 0.6431 \\
\hline Log-L & -1059.3783 & -914.0194 & -1035.4341 & -872.7333 & -2023.1226 \\
\hline
\end{tabular}

Note. $^{* * *},{ }^{* *}$, and ${ }^{*}$ denote a significance level of $1 \%, 5 \%$, and $10 \%$, respectively. The $t$-statistic is in parentheses. 
economic, and comprehensive aspects of innovation quality rather than just its technological aspect measured by the number of patents.

As for the effect of tax preferences, they fail the 5\% significance level test in the estimated results of all five forms, indicating that they cannot enhance regional innovation quality. It is inconsistent with Ernst et al. [13] and Mukherjee et al. [14], who considered that tax preferences are beneficial to innovation quality due to the difference in the research sample, perspective, and empirical model. Their studies were based on the firm perspective and used nonspatial econometric methods for analysis. In contrast, this study is based on the regional level that includes innovation subjects such as firms, institutions, and financial institutions. Meanwhile, it uses a spatial econometric model to portray the spatially relevant features of government R\&D funding and innovation quality, which may be relatively more accurate. Besides, the effect of tax preferences is not significant, but that of subsidies is positive and significant, which is inconsistent with Hypothesis 1 but validates Hypothesis 2 . It may be due to the characteristic of tax preferences and the shortcomings of China's tax preference policy. Firstly, as expost subsidy policies, tax preference policies cannot meet the funds for innovation immediately. Further, in China, the current tax preferences are mainly based on enterprise income tax and aim to stimulate the inputs of innovation, thus not stimulating innovation quality directly [17]. Finally, the effect of tax preferences is deeply affected by taxable income, and fluctuating taxable income makes the intensity of tax preferences fluctuate greatly, which is detrimental to the long-term planning of high-quality innovation [47]. It can be found that there are some cities with negative profits in the sample, such as Taiyuan and Yangquan. These cities are likely to have little or even no taxable income for enterprise income tax, leading to tax preferences that may not work for them as they should [26].

For control variables, firstly, although the improvement of the institutional environment enhances local innovation quality, it is not conducive to the advancement of the innovation quality in neighboring regions. It may be because regions with a sound institutional environment attract the inflow of innovation resources but are not conducive to improving innovation quality in neighboring regions with a poor institutional environment. In the meantime, the effect of firm size on regional innovation quality is not significant, which is inconsistent with our expectation. It may be since both large and small firms have advantages in improving innovation quality. Thus, governments cannot decide whether to subsidize just based on the scale of firms alone. Furthermore, inconsistent with the expectation, the effect of the infrastructure level on regional innovation quality is not significant. One possible reason is that government investment in infrastructure may crowd out funds that will otherwise be invested in R\&D activities, which is not conducive to improving regional innovation quality.

In order to analyze the influence path of government $R \& D$ funding on regional innovation quality further, this study adopts the decomposition method provided by Lesage and Pace $[61,62]$ to divide the combined impact of government R\&D funding on regional innovation quality into two parts: direct effects and spillover effects, respectively. The former represents the average impact of government $R \& D$ funding on local innovation quality; the latter represents the average impact of government $R \& D$ funding on innovation quality in neighboring regions. The estimated results are reported in Table 5. It can be found that the increased strength of local subsidies is conducive to improving their innovation quality and the innovation quality in neighboring regions. The reasons for the positive direct effect have already been analyzed above, and the positive spillover effect may be related to the phenomenon of "competition for innovation" among regions. The fierce funding competition makes all regions devote themselves to increasing the input of regional innovation resources, attracting the inflow of innovation resources, and optimizing the allocation of regional innovation resources. Thus, government $R \& D$ funding is conducive to improving the innovation quality in neighboring regions. Besides, the direct, spillover, and total effects of tax preferences do not pass the significance test.

4.3. Robustness Tests. This study mainly carries out three kinds of robustness tests, which consider possible lagged effects of government R\&D funding on regional innovation quality and replace the measurement variables of government R\&D funding and the spatial weighting matrix. Firstly, the model is re-estimated by lagging all independent and control variables by one and two periods, respectively, since it may take time for government $\mathrm{R} \& \mathrm{D}$ funding to be implemented and to eventually improve regional innovation quality. Also, regions with previously high innovation quality may be more favored by government $R \& D$ funding [4], so lagging government R\&D funding and control variables can reduce the interference of this reciprocal causality on the estimated results. Secondly, the model is re-estimated based on other variables measuring government $R \& D$ funding (i.e., the size and the intensity of it), as mentioned earlier (note that this paper discusses two forms of government R\&D funding: subsidies and tax preferences, which are, respectively, measured by fiscal S\&T expenditures as a share of regional GDP and enterprise income tax as a share of regional GDP in the benchmark regression. Here, in the robustness tests, the size of subsidies is re-measured by the fiscal S\&T expenditures, and the size of tax preferences is remeasured by the enterprise income tax revenue. Meanwhile, the intensity of subsidies is re-measured by fiscal S\&T expenditures as a share of total fiscal expenditures, and the intensity of tax preferences is re-measured by enterprise income tax as a share of total fiscal revenue). Thirdly, the model is re-estimated based on the spatial weight matrix of geographic distance and economic distance, respectively. The specific settings of the spatial weight matrix are shown in equations (10) and (11), where $W_{2}$ and $W_{3}$ are the spatial weight matrix of geographic distance and economic distance, respectively, $i$ and $j$ denote regions $i$ and $j, d$ is the spherical distance between the two regions, and GDP is the annual average of GDP per capita for each region in the sample period: 
TABLE 5: Estimated results of the direct, indirect, and total effects based on the SDM.

\begin{tabular}{lccc}
\hline Variables & Direct effects & Indirect effects & Total effects \\
\hline \multirow{2}{*}{ Subsidy } & $0.1234^{* * *}$ & $0.1033^{* *}$ & $0.2267^{* * *}$ \\
& $(7.5099)$ & $(2.1831)$ & $(4.5807)$ \\
\hline \multirow{2}{*}{ Tax } & 0.0191 & -0.0283 & -0.0091 \\
& $(0.7687)$ & $(-0.3689)$ & $(-0.1178)$ \\
\hline
\end{tabular}

Note. $^{* * *},{ }^{* *}$, and ${ }^{*}$ denote a significance level of $1 \%, 5 \%$, and $10 \%$, respectively. The $t$-statistic is in parentheses.

$$
\begin{aligned}
& W_{2}= \begin{cases}\frac{1}{|d|}, & i \neq j, \\
0, & i=j,\end{cases} \\
& W_{3}= \begin{cases}\frac{1}{\left|\mathrm{GDP}_{i}-\mathrm{GDP}_{j}\right|}, & i \neq j, \\
0, & i=j .\end{cases}
\end{aligned}
$$

The estimated results are reported in Table 6 . It can be found that the coefficients of subsidies are all significantly positive at the $1 \%$ significant level, while those of tax preferences are not significantly negative. It indicates that subsidies can enhance regional innovation quality, while tax preferences cannot enhance regional innovation quality. Thus, the previous empirical results are robust and reliable.

\subsection{Tests of Influence Mechanisms and Identification of the Spillover Effect}

4.4.1. Tests of Influence Mechanisms. Theoretical analysis shows that the impact of subsidies on regional innovation quality is mainly manifested as follows. The resource attributes of subsidies enable direct innovation subjects to increase innovation resources, and their signaling attributes enable indirect innovation subjects to increase innovation support to the direct innovation subjects, thus contributing to the improvement of regional innovation quality (considering that the previous empirical results show that subsidies can significantly improve regional innovation quality, while tax preferences cannot improve it, this study focuses on examining the mechanism of subsidies on regional innovation quality). This section will empirically test each of these mechanisms. Firstly, to test whether subsidies can increase innovation resources by direct innovation subjects and then impact regional innovation quality, this paper develops an SDM with subsidies as the independent variable and innovation resources (Resources) as the dependent variable. It should be noted that three forms of subsidies are used in this section, namely, subsidies as a share of GDP (Subsidy1), the scale of subsidies (Subsidy2), and subsidies as a share of fiscal expenditure (Subsidy3) to enhance the reliability of the estimated results (note that Subsidy1, Subsidy2, and Subsidy3 are three measurements of subsidies mentioned earlier). The results are shown in Table 7 . Secondly, to test whether subsidies can increase indirect innovation subjects' innovation support and then influence regional innovation quality, this paper develops an SDM with subsidies as the independent variable and innovation support (Support) as the dependent variable. Also, Subsidy1, Subsidy2, and Subsidy3 are used to measure subsidies. The estimated results are shown in Table 8. Note that the definition and description of data sources for Subsidy1, Subsidy2, Subsidy3, Resources, and Support have been described in the description of variables. The specific analysis is as follows:

As shown in Table 7, for the impact of subsidies on the innovation resources of regional direct innovation subjects, the direct effects of Subsidy1, Subsidy2, and Subsidy3 are all significantly positive, while the estimated coefficients of the spillover effects are mostly negative. It indicates that the increase in local subsidies can promote local direct innovation subjects to increase innovation resources while decrease those in neighboring regions. The reason may be that regions with larger subsidies attract the inflow of innovation resources from geographically adjacent and economically nearby regions.

Table 8 shows the results of the impact of subsidies on the innovation support of regional indirect innovation subjects. In terms of direct effects, it shows that the estimated coefficients of Subsidy1, Subsidy2, and Subsidy3 are all significantly positive, indicating that local subsidies can promote local indirect innovation subjects to increase innovation support. However, the estimated coefficient of the spillover effect is not significant. In the Chinese context, the positioning of indirect innovation subjects (e.g., banks) to serve local areas and administrative barriers may make it difficult for subsidies to attract banks from other places to increase their support for local innovation.

4.4.2. Identification of the Spillover Effect. From the results in Table 5, it can be seen that subsidies enhance the innovation quality of neighboring regions (i.e., there is a spillover effect) due to the phenomenon of spatial competition for subsidies, as suggested in the previous analysis. Here, this study refers to Bian et al. [19] for further identification (the identification idea of Bian et al. [19] is as follows. Firstly, use Moran's I test for preliminary identification; secondly, build a spatial econometric model and identify it further based on the coefficient of the spatial lag term. Here, the result of Moran's I test indicates the existence of spatial competition for subsidies. However, to save space, it has not been reported in this section). To this end, an SLM with subsidies as the dependent variable is developed. The spatial lag coefficient $(\rho)$ of subsidies is tested to examine whether there is spatial competition for subsidies. Subsidy1, Subsidy2, and Subsidy 3 are used to measure subsidies as mentioned above, and the estimated results are shown in Table 9. It can be found that $\rho$ for all three measuring forms passes the test at the $1 \%$ significance level, indicating a positive correlation between subsidies, that is, when a region increases its subsidies, regions that are geographically close to it and have small economic disparities with it will also increase subsidies strategically. Thus, it proves that there is spatial competition between regions in terms of subsidies. 
TABLE 6: Results of the robustness test.

\begin{tabular}{|c|c|c|c|c|c|c|}
\hline & \multicolumn{2}{|c|}{ Consider the lagged effects } & \multicolumn{2}{|c|}{$\begin{array}{c}\text { Replace measurement } \\
\text { variables of government } \\
\text { R\&D funding }\end{array}$} & \multicolumn{2}{|c|}{ Replace the spatial weight matrix } \\
\hline & One period & Two periods & Size & Intensity & Geography distance & Economic distance \\
\hline Subsidy & $\begin{array}{c}0.1295^{* * *} \\
(7.2784)\end{array}$ & $\begin{array}{c}0.0963^{* * *} \\
(5.0052)\end{array}$ & $\begin{array}{c}0.1656^{* * *} \\
(9.6374)\end{array}$ & $\begin{array}{c}0.1490^{* * *} \\
(7.8619)\end{array}$ & $\begin{array}{c}0.0988^{* * *} \\
(4.7271)\end{array}$ & $\begin{array}{c}0.1390^{* * *} \\
(5.7808)\end{array}$ \\
\hline Tax & $\begin{array}{c}0.0115 \\
(0.4279) \\
\end{array}$ & $\begin{array}{c}0.0405 \\
(1.3768) \\
\end{array}$ & $\begin{array}{c}0.0916^{* * *} \\
(4.3620) \\
\end{array}$ & $\begin{array}{c}0.0092 \\
(0.3215) \\
\end{array}$ & $\begin{array}{c}0.0086 \\
(0.2882) \\
\end{array}$ & $\begin{array}{c}0.0394 \\
(1.1964)\end{array}$ \\
\hline Resources & $\begin{array}{l}0.2519^{* * *} \\
(15.6856) \\
\end{array}$ & $\begin{array}{c}0.2426^{* * *} \\
(14.6118)\end{array}$ & $\begin{array}{c}0.1480^{* * *} \\
(8.5438)\end{array}$ & $\begin{array}{c}0.2499^{* * *} \\
(15.6723)\end{array}$ & $\begin{array}{l}0.2621^{* * *} \\
(14.6832)\end{array}$ & $\begin{array}{c}0.3024^{* * *} \\
(16.3099)\end{array}$ \\
\hline Support & $\begin{array}{c}0.1865^{* * *} \\
(6.2034)\end{array}$ & $\begin{array}{c}0.2121^{* * *} \\
(6.2609)\end{array}$ & $\begin{array}{c}0.2020^{* * *} \\
(7.4744) \\
\end{array}$ & $\begin{array}{c}0.2176^{* * *} \\
(7.6062) \\
\end{array}$ & $\begin{array}{c}0.2434^{* * *} \\
(6.7173)\end{array}$ & $\begin{array}{c}0.2002^{* * *} \\
(5.0483)\end{array}$ \\
\hline Economy & $\begin{array}{c}0.3865^{* * *} \\
(12.8981) \\
\end{array}$ & $\begin{array}{c}0.3510^{* * *} \\
(10.4551) \\
\end{array}$ & $\begin{array}{c}0.2336^{* * *} \\
(7.3139) \\
\end{array}$ & $\begin{array}{c}0.3159^{* * *} \\
(9.6777) \\
\end{array}$ & $\begin{array}{c}0.3547^{* * *} \\
(10.2791) \\
\end{array}$ & $\begin{array}{c}0.3175^{* * *} \\
(8.2847) \\
\end{array}$ \\
\hline Industry & $\begin{array}{c}0.0903 * \\
(1.9217)\end{array}$ & $\begin{array}{c}0.0773 \\
(1.5245)\end{array}$ & $\begin{array}{c}0.1387^{* * *} \\
(3.0412)\end{array}$ & $\begin{array}{c}0.1351^{* * *} \\
(2.8139)\end{array}$ & $\begin{array}{c}0.1144 * * \\
(2.1943)\end{array}$ & $\begin{array}{c}-0.0004 \\
(-0.0085)\end{array}$ \\
\hline Size & $\begin{array}{c}-0.0144 \\
(-0.7097) \\
\end{array}$ & $\begin{array}{c}0.0042 \\
(0.1825) \\
\end{array}$ & $\begin{array}{c}0.0211 \\
(1.0675) \\
\end{array}$ & $\begin{array}{c}0.0001 \\
(0.0022) \\
\end{array}$ & $\begin{array}{c}-0.0177 \\
(-0.7346) \\
\end{array}$ & $\begin{array}{c}-0.0003 \\
(-0.0136) \\
\end{array}$ \\
\hline Infrastructure & $\begin{array}{c}-0.0061 \\
(-0.2476)\end{array}$ & $\begin{array}{c}-0.0171 \\
(-0.6674)\end{array}$ & $\begin{array}{c}-0.0336 \\
(-1.4328) \\
\end{array}$ & $\begin{array}{c}-0.0101 \\
(-0.4136)\end{array}$ & $\begin{array}{c}-0.0344 \\
(-1.2215)\end{array}$ & $\begin{array}{c}-0.0377 \\
(-1.1920)\end{array}$ \\
\hline Opening & $\begin{array}{c}0.0364^{* * *} \\
(3.2359) \\
\end{array}$ & $\begin{array}{c}0.0416^{* * *} \\
(3.3602)\end{array}$ & $\begin{array}{c}0.0250^{* * *} \\
(2.2922) \\
\end{array}$ & $\begin{array}{c}0.0333^{* * *} \\
(2.9304) \\
\end{array}$ & $\begin{array}{c}0.0386^{* * *} \\
(2.9890) \\
\end{array}$ & $\begin{array}{l}0.0318^{* *} \\
(2.2050)\end{array}$ \\
\hline Institution & $\begin{array}{c}-0.1742^{* * *} \\
(-5.3986) \\
\end{array}$ & $\begin{array}{c}-0.1679^{* * *} \\
(-3.8075) \\
\end{array}$ & $\begin{array}{c}-0.1325^{* * *} \\
(-3.8520) \\
\end{array}$ & $\begin{array}{c}-0.1912^{* * *} \\
(-5.3639) \\
\end{array}$ & $\begin{array}{c}-0.1074^{* * *} \\
(-2.7627) \\
\end{array}$ & $\begin{array}{c}-0.1309^{* * *} \\
(-2.9552)\end{array}$ \\
\hline Education & $\begin{array}{c}0.0404^{* * *} \\
(3.5553) \\
\end{array}$ & $\begin{array}{c}0.0303^{* * *} \\
(2.3777) \\
\end{array}$ & $\begin{array}{c}0.0113^{* * *} \\
(1.0056) \\
\end{array}$ & $\begin{array}{c}0.0312^{* * *} \\
(2.6867)\end{array}$ & $\begin{array}{c}0.0379^{* * *} \\
(2.8273) \\
\end{array}$ & $\begin{array}{c}0.0355^{* * *} \\
(2.6360) \\
\end{array}$ \\
\hline $\mathrm{W}^{*}$ Subsidy & $\begin{array}{c}0.0266 \\
(0.5327)\end{array}$ & $\begin{array}{c}0.2800^{* *} \\
(2.2800)\end{array}$ & $\begin{array}{c}0.0441 \\
(1.0340)\end{array}$ & $\begin{array}{c}0.0466 \\
(1.0287)\end{array}$ & $\begin{array}{c}0.0085 \\
(0.1619)\end{array}$ & $\begin{array}{c}0.0396 \\
(0.5992)\end{array}$ \\
\hline $\mathrm{W}^{*} \operatorname{Tax}$ & $\begin{array}{c}0.0951 \\
(1.1704)\end{array}$ & $\begin{array}{c}-0.2807 \\
(-1.4357)\end{array}$ & $\begin{array}{l}-0.0980^{*} \\
(-1.8559)\end{array}$ & $\begin{array}{c}-0.1783^{* *} \\
(-2.3891)\end{array}$ & $\begin{array}{l}0.1314^{*} \\
(1.7013)\end{array}$ & $\begin{array}{c}0.0373 \\
(0.4494)\end{array}$ \\
\hline $\mathrm{W}^{*}$ Resources & $\begin{array}{c}-0.0531 \\
(-0.9799) \\
\end{array}$ & $\begin{array}{c}-0.0232 \\
(-0.1417) \\
\end{array}$ & $\begin{array}{c}-0.0085 \\
(-0.1710) \\
\end{array}$ & $\begin{array}{c}-0.0183 \\
(-0.3800)\end{array}$ & $\begin{array}{c}-0.1150^{* *} \\
(-2.4019) \\
\end{array}$ & $\begin{array}{c}-0.0467 \\
(-0.9274)\end{array}$ \\
\hline $\mathrm{W}^{*}$ Support & $\begin{array}{c}-0.0361 \\
(-0.4068)\end{array}$ & $\begin{array}{c}-0.5263^{* *} \\
(-2.3175)\end{array}$ & $\begin{array}{c}-0.0329 \\
(-0.5077)\end{array}$ & $\begin{array}{c}-0.0364 \\
(-0.5272)\end{array}$ & $\begin{array}{c}-0.3751^{* * *} \\
(-4.3627) \\
\end{array}$ & $\begin{array}{l}-0.1925^{*} \\
(-1.9273)\end{array}$ \\
\hline $\mathrm{W}^{*}$ Economy & $\begin{array}{c}-0.0174 \\
(-0.2016) \\
\end{array}$ & $\begin{array}{c}0.0274 \\
(0.1398) \\
\end{array}$ & $\begin{array}{c}-0.0057 \\
(-1.1255) \\
\end{array}$ & $\begin{array}{c}-0.0359 \\
(-0.4578) \\
\end{array}$ & $\begin{array}{c}-0.1027 \\
(-1.1960) \\
\end{array}$ & $\begin{array}{c}0.1474 \\
(1.5047)\end{array}$ \\
\hline $\mathrm{W}^{*}$ Industry & $\begin{array}{c}0.0608 \\
(0.4256) \\
\end{array}$ & $\begin{array}{c}0.1192 \\
(0.2913) \\
\end{array}$ & $\begin{array}{c}0.0122 \\
(0.1025)\end{array}$ & $\begin{array}{c}0.0083 \\
(0.0658)\end{array}$ & $\begin{array}{c}0.0016 \\
(0.0114)\end{array}$ & $\begin{array}{c}0.4495^{* * *} \\
(2.9638)\end{array}$ \\
\hline $\mathrm{W}^{*}$ Size & $\begin{array}{c}-0.0905 \\
(-1.4982) \\
\end{array}$ & $\begin{array}{c}-0.0321 \\
(-0.2254)\end{array}$ & $\begin{array}{c}-0.0683 \\
(-1.3903) \\
\end{array}$ & $\begin{array}{c}-0.0623 \\
(-1.2241) \\
\end{array}$ & $\begin{array}{c}0.0586 \\
(0.0114) \\
\end{array}$ & $\begin{array}{c}-0.0949 \\
(-1.5774) \\
\end{array}$ \\
\hline $\mathrm{W}^{*}$ Infrastructure & $\begin{array}{c}0.0369 \\
(0.5142)\end{array}$ & $\begin{array}{l}0.4113^{*} \\
(1.9199)\end{array}$ & $\begin{array}{c}0.0733 \\
(1.2039)\end{array}$ & $\begin{array}{c}0.0966 \\
(1.5309)\end{array}$ & $\begin{array}{c}0.0422 \\
(0.5672)\end{array}$ & $\begin{array}{c}-0.0757 \\
(-0.9662)\end{array}$ \\
\hline $\mathrm{W}^{*}$ Opening & $\begin{array}{c}0.0052 \\
(0.1680) \\
\end{array}$ & $\begin{array}{c}-0.0674 \\
(-0.8096)\end{array}$ & $\begin{array}{c}0.0249 \\
(0.9288)\end{array}$ & $\begin{array}{c}0.0171 \\
(0.6109) \\
\end{array}$ & $\begin{array}{c}0.0088 \\
(0.2447) \\
\end{array}$ & $\begin{array}{c}-0.0346 \\
(-0.9770)\end{array}$ \\
\hline $\mathrm{W}^{*}$ Institution & $\begin{array}{l}0.1496^{*} \\
(1.6486) \\
\end{array}$ & $\begin{array}{l}0.3590^{*} \\
(1.7155)\end{array}$ & $\begin{array}{c}0.2320^{* * *} \\
(2.9486) \\
\end{array}$ & $\begin{array}{c}0.2196^{* * *} \\
(2.7206) \\
\end{array}$ & $\begin{array}{c}0.0996 \\
(1.0862) \\
\end{array}$ & $\begin{array}{c}0.0072 \\
(0.0671) \\
\end{array}$ \\
\hline $\mathrm{W}^{*}$ Education & $\begin{array}{c}-0.0417 \\
(-1.1061)\end{array}$ & $\begin{array}{c}-0.0351 \\
(-0.3586)\end{array}$ & $\begin{array}{c}-0.0375 \\
(-1.1255) \\
\end{array}$ & $\begin{array}{c}-0.0406 \\
(-1.1936) \\
\end{array}$ & $\begin{array}{c}0.1056^{* * *} \\
(2.9514)\end{array}$ & $\begin{array}{c}-0.0259 \\
(-0.7071)\end{array}$ \\
\hline $\mathrm{W}^{*}$ Innovation & $\begin{array}{c}0.0993^{* *} \\
(2.1438)\end{array}$ & $\begin{array}{l}0.8777^{* * *} \\
(32.3208) \\
\end{array}$ & $\begin{array}{c}0.1927^{* * *} \\
(4.7666)\end{array}$ & $\begin{array}{c}0.1967^{* * *} \\
(4.8767) \\
\end{array}$ & $\begin{array}{c}0.1827^{* * *} \\
(4.1576)\end{array}$ & $\begin{array}{c}0.1706^{* * *} \\
(3.5283) \\
\end{array}$ \\
\hline$\delta^{2}$ & 0.1671 & 0.1584 & 0.1509 & 0.1633 & 0.1768 & 0.1627 \\
\hline$\overline{R^{2}}$ & 0.6593 & 0.6148 & 0.6886 & 0.6631 & 0.6255 & 0.6732 \\
\hline Log-L & -882.7404 & -845.4902 & -786.7291 & -865.1183 & -784.4594 & -565.6055 \\
\hline
\end{tabular}

Note. $^{* * *},{ }^{* *}$, and ${ }^{*}$ denote a significance level of $1 \%, 5 \%$, and $10 \%$, respectively, and the $t$-statistic is in parentheses. According to the Hausman test, most models should be estimated with fixed effects, and thus, this study analyzes the results based on the estimation of time and space fixed effects for the sake of comparison. 
TABLE 7: Results of the impact mechanism test: impact on innovation resources.

\begin{tabular}{|c|c|c|c|c|c|c|}
\hline & & nonF & $\mathrm{sF}$ & $\mathrm{tF}$ & $\mathrm{stF}$ & $r$ \\
\hline \multirow{2}{*}{ Subsidy1 } & Direct effect & $\begin{array}{l}0.0421^{*} \\
(1.6946)\end{array}$ & $\begin{array}{l}0.0499^{*} \\
(1.9225)\end{array}$ & $\begin{array}{l}0.0432^{*} \\
(1.7216)\end{array}$ & $\begin{array}{l}0.0493^{*} \\
(2.0656)\end{array}$ & $\begin{array}{l}0.0434^{*} \\
(1.7212)\end{array}$ \\
\hline & Spillover effect & $\begin{array}{l}-0.1392^{* *} \\
(-2.2821)\end{array}$ & $\begin{array}{c}-0.1256 * \\
(-1.9258)\end{array}$ & $\begin{array}{l}-0.0758 \\
(-1.165)\end{array}$ & $\begin{array}{c}-0.0381 \\
(-0.6174)\end{array}$ & $\begin{array}{c}-0.0681 \\
(-1.0432)\end{array}$ \\
\hline \multirow{2}{*}{ Subsidy2 } & Direct effect & $\begin{array}{c}0.3549^{* * *} \\
(18.6667)\end{array}$ & $\begin{array}{c}0.3367^{* * * *} \\
(17.1314)\end{array}$ & $\begin{array}{c}0.3575^{* * *} \\
(18.6371)\end{array}$ & $\begin{array}{c}0.3394^{* * *} \\
(18.4044)\end{array}$ & $\begin{array}{c}0.3537^{* * *} \\
(18.6869)\end{array}$ \\
\hline & Spillover effect & $\begin{array}{c}-0.2089^{* * *} \\
(-3.6912) \\
\end{array}$ & $\begin{array}{l}0.2175^{* * *} \\
(-3.8151) \\
\end{array}$ & $\begin{array}{c}-0.1517^{* * *} \\
(-2.8521)\end{array}$ & $\begin{array}{c}-0.1537^{* * *} \\
(-2.8922) \\
\end{array}$ & $\begin{array}{l}-0.152^{* * *} \\
(-2.8037) \\
\end{array}$ \\
\hline \multirow{2}{*}{ Subsidy3 } & Direct effect & $\begin{array}{c}0.0695^{* * *} \\
(2.5278)\end{array}$ & $\begin{array}{c}0.0748^{* * *} \\
(2.6487)\end{array}$ & $\begin{array}{c}0.0740^{* * *} \\
(2.6932)\end{array}$ & $\begin{array}{c}0.0807^{* * * *} \\
(2.8412)\end{array}$ & $\begin{array}{c}0.0751^{* * *} \\
(2.7798)\end{array}$ \\
\hline & Spillover effect & $\begin{array}{l}0.2162^{* * *} \\
(-3.3301)\end{array}$ & $\begin{array}{c}-0.1950^{* * *} \\
(-2.8162)\end{array}$ & $\begin{array}{c}-0.0951 \\
(-1.3188)\end{array}$ & $\begin{array}{c}-0.0566 \\
(-0.7660)\end{array}$ & $\begin{array}{c}-0.0832 \\
(-1.1439)\end{array}$ \\
\hline
\end{tabular}

Note. $^{* * *},{ }^{* *}$, and ${ }^{*}$ denote a significance level of $1 \%, 5 \%$, and $10 \%$, respectively. The $t$-statistic is in parentheses.

TABLE 8: Results of the impact mechanism test: impact on innovation support.

\begin{tabular}{|c|c|c|c|c|c|c|}
\hline & & nonF & $\mathrm{sF}$ & $\mathrm{tF}$ & $\mathrm{stF}$ & $r$ \\
\hline \multirow{4}{*}{ Subsidy1 } & \multirow{2}{*}{ Direct effect } & $0.1521^{* * *}$ & $0.1534^{* * *}$ & $0.1456^{* * *}$ & $0.1469^{* * *}$ & $0.1458^{* * *}$ \\
\hline & & $(11.2262)$ & $(10.8430)$ & (10.5898) & (11.3750) & $(11.1162)$ \\
\hline & \multirow{2}{*}{ Spillover effect } & $0.1256^{* * *}$ & $0.1114^{* * *}$ & 0.0246 & -0.0120 & 0.0212 \\
\hline & & $(2.8525)$ & $(2.3940)$ & $(0.5585)$ & $(-0.2726)$ & $(0.4747)$ \\
\hline \multirow{4}{*}{ Subsidy2 } & \multirow{2}{*}{ Direct effect } & $0.0356^{* * *}$ & $0.0404^{* * *}$ & $0.0291^{* *}$ & $0.0332^{* * *}$ & $0.0291^{* *}$ \\
\hline & & $(2.8296)$ & $(2.9614)$ & $(2.2801)$ & $(2.7043)$ & $(2.3722)$ \\
\hline & \multirow{2}{*}{ Spillover effect } & $0.0944 *$ & 0.0773 & 0.0076 & -0.0217 & 0.0089 \\
\hline & & $(1.9063)$ & $(1.3962)$ & $(0.1806)$ & $(-0.5081)$ & $(0.2047)$ \\
\hline \multirow{4}{*}{ Subsidy3 } & \multirow{2}{*}{ Direct effect } & $0.0714^{* * *}$ & $0.0740^{* * *}$ & $0.0643^{* * *}$ & $0.0654^{* * *}$ & $0.0648^{* * *}$ \\
\hline & & $(4.5724)$ & $(4.4483)$ & $(4.2198)$ & $(4.2664)$ & $(4.0507)$ \\
\hline & \multirow{2}{*}{ Spillover effect } & $0.1669^{* * *}$ & $0.1599^{* * *}$ & 0.0551 & 0.0248 & 0.0561 \\
\hline & & $(3.1771)$ & (2.7489) & $(1.0628)$ & $(0.5024)$ & $(1.1500)$ \\
\hline
\end{tabular}

Note. $^{* * *},{ }^{* *}$, and ${ }^{*}$ denote a significance level of $1 \%, 5 \%$, and $10 \%$, respectively. The $t$-statistic is in parentheses.

TABLE 9: Identification of spatial competition effects of subsidies.

\begin{tabular}{lccc}
\hline & Subsidy1 & Subsidy2 & Subsidy3 \\
\hline$\rho$ & $0.3583^{* * *}$ & $0.2611^{* * *}$ & $0.2553^{* * *}$ \\
& $(9.9679)$ & $(8.9613)$ & $(7.7439)$ \\
\hline Controls & YES & YES & YES \\
$\delta^{2}$ & 0.3438 & 0.4452 & 0.2868 \\
$R^{2}$ & 0.1582 & 0.6391 & 0.4771 \\
Log-L & -1615.3235 & -1862.7471 & -1426.7387 \\
\hline
\end{tabular}

Note. ${ }^{* * *},{ }^{* *}$, and ${ }^{*}$ denote a significance level of $1 \%, 5 \%$, and $10 \%$, respectively, and the $t$-statistic is in parentheses. The regression results reported are based on time and space fixed effects; dynamic spatial lag models are built to test again, and the results remain consistent, but are not reported to save space.

Thus, combined with the results of the above tests on the mechanism of subsidies affecting regional innovation quality, it can be seen that the spillover effect of subsidies on the innovation quality in neighboring regions (i.e., the impact of subsidies on improving the innovation quality in neighboring regions) can be reflected as follows: when one region increases the intensity of subsidies, neighboring regions usually strategically increase subsidies, which leads to an increase in innovation resources for direct innovation subjects and an increase in innovation support for indirect innovation subjects in neighboring regions, attracts the inflow of innovation resources from other regions, and, thus, helps neighboring regions to improve regional innovation quality.

\section{Further Analysis and Discussion}

\subsection{Heterogeneity Tests}

5.1.1. Heterogeneity of the City Location. Among the 283 cities, there are 98 Eastern cities, 100 Middle cities, and 85 Western cities (the Eastern cities are located in Hebei, Liaoning, Jiangsu, Zhejiang, Fujian, Shandong, Guangdong, and Hainan. The Middle cities are located in Shanxi, Jilin, 
TABle 10: Estimated results of heterogeneity tests.

\begin{tabular}{|c|c|c|c|c|c|}
\hline & \multicolumn{3}{|c|}{ Heterogeneity of the city location } & \multicolumn{2}{|c|}{ Heterogeneity of the city administrative hierarchy } \\
\hline & $\begin{array}{l}\text { Eastern } \\
\text { cities }\end{array}$ & $\begin{array}{l}\text { Middle } \\
\text { cities }\end{array}$ & $\begin{array}{l}\text { Western } \\
\text { cities }\end{array}$ & $\begin{array}{l}\text { Cities with higher administrative } \\
\text { hierarchy }\end{array}$ & $\begin{array}{l}\text { Cities with general administrative } \\
\text { hierarchy }\end{array}$ \\
\hline Subsidy & $\begin{array}{l}-0.0622^{* *} \\
(-2.1304) \\
\end{array}$ & $\begin{array}{c}0.1252^{* * *} \\
(4.9261) \\
\end{array}$ & $\begin{array}{c}0.1010^{* * *} \\
(3.6978) \\
\end{array}$ & $\begin{array}{c}-0.2828^{* * *} \\
(-3.8747) \\
\end{array}$ & $\begin{array}{c}0.0856^{* * *} \\
(5.0891) \\
\end{array}$ \\
\hline Tax & $\begin{array}{c}0.0981^{* * *} \\
(2.7189) \\
\end{array}$ & $\begin{array}{c}-0.1607^{* * *} \\
(-5.3033) \\
\end{array}$ & $\begin{array}{c}-0.1212^{* * *} \\
(15.7478) \\
\end{array}$ & $\begin{array}{c}0.1851^{* * *} \\
(3.2489) \\
\end{array}$ & $\begin{array}{l}-0.0408^{*} \\
(-1.9289)\end{array}$ \\
\hline Resources & $\begin{array}{l}0.2503^{* * *} \\
(15.4173) \\
\end{array}$ & $\begin{array}{r}0.2546^{* * *} \\
(15.8718) \\
\end{array}$ & $\begin{array}{l}0.2542^{* * *} \\
(15.7478) \\
\end{array}$ & $\begin{array}{l}0.2350^{* * *} \\
(13.8213)\end{array}$ & $\begin{array}{l}0.2257^{* * *} \\
(13.3414)\end{array}$ \\
\hline Support & $\begin{array}{c}0.0430^{* * *} \\
(7.8741) \\
\end{array}$ & $\begin{array}{c}0.2453^{* * *} \\
(8.7266) \\
\end{array}$ & $\begin{array}{c}0.2450^{* * *} \\
(8.6525) \\
\end{array}$ & $\begin{array}{c}0.1797^{* * *} \\
(5.5944)\end{array}$ & $\begin{array}{c}0.1431^{* * *} \\
(4.2035) \\
\end{array}$ \\
\hline Economy & $\begin{array}{l}0.4225^{* * *} \\
(13.8172) \\
\end{array}$ & $\begin{array}{l}0.4176^{* * *} \\
(13.3931) \\
\end{array}$ & $\begin{array}{l}0.4239^{* * *} \\
(13.8922) \\
\end{array}$ & $\begin{array}{l}0.3749^{* * *} \\
(12.0447)\end{array}$ & $\begin{array}{l}0.3622^{* * *} \\
(11.4288)\end{array}$ \\
\hline Industry & $\begin{array}{l}0.0843^{*} \\
(1.7610) \\
\end{array}$ & $\begin{array}{c}0.0651 \\
(1.3664) \\
\end{array}$ & $\begin{array}{c}0.0765 \\
(1.5958) \\
\end{array}$ & $\begin{array}{c}0.0551 \\
(1.1350) \\
\end{array}$ & $\begin{array}{c}0.0326 \\
(0.6822) \\
\end{array}$ \\
\hline Size & $\begin{array}{c}-0.0195 \\
(-0.9413) \\
\end{array}$ & $\begin{array}{c}0.0052 \\
(0.2494)\end{array}$ & $\begin{array}{c}-0.0136 \\
(-0.6592) \\
\end{array}$ & $\begin{array}{c}-0.0124 \\
(-0.6052)\end{array}$ & $\begin{array}{c}-0.0085 \\
(-0.4148) \\
\end{array}$ \\
\hline Infrastructure & $\begin{array}{c}0.0055 \\
(0.2194) \\
\end{array}$ & $\begin{array}{c}0.0138 \\
(0.5613) \\
\end{array}$ & $\begin{array}{c}-0.0045 \\
(-0.1856) \\
\end{array}$ & $\begin{array}{c}-0.0161 \\
(-0.6601) \\
\end{array}$ & $\begin{array}{c}-0.0178 \\
(-0.7256) \\
\end{array}$ \\
\hline Opening & $\begin{array}{c}0.0527^{* * *} \\
(4.5568) \\
\end{array}$ & $\begin{array}{c}0.0487^{* * *} \\
(4.2469) \\
\end{array}$ & $\begin{array}{c}0.0466^{* * *} \\
(4.0612) \\
\end{array}$ & $\begin{array}{c}0.0408^{* * *} \\
(3.5682) \\
\end{array}$ & $\begin{array}{c}0.0378^{* * *} \\
(3.3106) \\
\end{array}$ \\
\hline Institution & $\begin{array}{c}-0.2852^{* * *} \\
(-6.8726) \\
\end{array}$ & $\begin{array}{c}-0.2344^{* * *} \\
(-5.9675)\end{array}$ & $\begin{array}{c}-0.1946^{* * *} \\
(-5.3351) \\
\end{array}$ & $\begin{array}{c}-0.2518^{* * *} \\
(-6.7071) \\
\end{array}$ & $\begin{array}{c}-0.2507^{* * *} \\
(-6.7179) \\
\end{array}$ \\
\hline Education & $\begin{array}{c}0.0430^{* * *} \\
(3.6693) \\
\end{array}$ & $\begin{array}{c}0.0407^{* * *} \\
(3.4907) \\
\end{array}$ & $\begin{array}{c}0.0457^{* * *} \\
(3.8854) \\
\end{array}$ & $\begin{array}{c}0.0356^{* * *} \\
(3.0228) \\
\end{array}$ & $\begin{array}{c}0.0338^{* * *} \\
(2.8987) \\
\end{array}$ \\
\hline W*Subsidy & $\begin{array}{c}-0.0232 \\
(-0.3289) \\
\end{array}$ & $\begin{array}{l}0.1195^{* *} \\
(1.9770) \\
\end{array}$ & $\begin{array}{c}-0.0199 \\
(-0.2704) \\
\end{array}$ & $\begin{array}{c}0.1353 \\
(0.7002) \\
\end{array}$ & $\begin{array}{c}0.0433 \\
(1.0120) \\
\end{array}$ \\
\hline $\mathrm{W}^{*} \operatorname{Tax}$ & $\begin{array}{c}0.0328 \\
(0.3762)\end{array}$ & $\begin{array}{l}-0.1321^{*} \\
(-1.8380)\end{array}$ & $\begin{array}{c}-0.0161 \\
(-0.1839) \\
\end{array}$ & $\begin{array}{c}-0.0564 \\
(-0.3735) \\
\end{array}$ & $\begin{array}{l}-0.0932^{*} \\
(-1.7476)\end{array}$ \\
\hline $\mathrm{W} *$ Resources & $\begin{array}{c}-0.0336 \\
(-0.6862) \\
\end{array}$ & $\begin{array}{c}-0.0323 \\
(-0.6646) \\
\end{array}$ & $\begin{array}{c}-0.0485 \\
(-0.9855) \\
\end{array}$ & $\begin{array}{c}-0.0044 \\
(-0.0866)\end{array}$ & $\begin{array}{c}-0.0162 \\
(-0.3169)\end{array}$ \\
\hline W*Support & $\begin{array}{c}-0.0746 \\
(-1.0948) \\
\end{array}$ & $\begin{array}{c}-0.0567 \\
(-0.8366) \\
\end{array}$ & $\begin{array}{c}-0.0872 \\
(-1.2859) \\
\end{array}$ & $\begin{array}{c}-0.0135 \\
(-0.1777) \\
\end{array}$ & $\begin{array}{c}0.0043 \\
(0.0533) \\
\end{array}$ \\
\hline $\mathrm{W}^{*}$ Economy & $\begin{array}{l}-0.0904 \\
(-1.1789) \\
\end{array}$ & $\begin{array}{c}-0.1053 \\
(-1.3649) \\
\end{array}$ & $\begin{array}{l}-0.0994 \\
(-1.2761) \\
\end{array}$ & $\begin{array}{c}-0.0549 \\
(-0.6936) \\
\end{array}$ & $\begin{array}{c}-0.0372 \\
(-0.4630) \\
\end{array}$ \\
\hline $\mathrm{W}^{*}$ Industry & $\begin{array}{c}-0.0071 \\
(-0.0579) \\
\end{array}$ & $\begin{array}{c}-0.0325 \\
(-0.2638) \\
\end{array}$ & $\begin{array}{c}-0.0089 \\
(-0.0718) \\
\end{array}$ & $\begin{array}{c}0.0252 \\
(0.2005) \\
\end{array}$ & $\begin{array}{c}-0.0185 \\
(-0.1499) \\
\end{array}$ \\
\hline $\mathrm{W}^{*}$ Size & $\begin{array}{l}-0.0622 \\
(-1.1855) \\
\end{array}$ & $\begin{array}{c}-0.0189 \\
(-0.3591)\end{array}$ & $\begin{array}{c}-0.0557 \\
(-1.0762)\end{array}$ & $\begin{array}{c}-0.0643 \\
(-1.2452) \\
\end{array}$ & $\begin{array}{c}-0.0707 \\
(-1.3733) \\
\end{array}$ \\
\hline $\mathrm{W}^{*}$ Infrastructure & $\begin{array}{c}0.0909 \\
(1.4116) \\
\end{array}$ & $\begin{array}{l}0.1053^{*} \\
(1.6559) \\
\end{array}$ & $\begin{array}{l}0.1107^{*} \\
(1.6720) \\
\end{array}$ & $\begin{array}{c}0.0995 \\
(1.5574) \\
\end{array}$ & $\begin{array}{l}0.1066^{*} \\
(1.6619) \\
\end{array}$ \\
\hline $\mathrm{W}^{*}$ Opening & $\begin{array}{c}0.0293 \\
(1.0269) \\
\end{array}$ & $\begin{array}{c}0.0286 \\
(1.0058) \\
\end{array}$ & $\begin{array}{c}0.0161 \\
(0.5744) \\
\end{array}$ & $\begin{array}{c}0.0167 \\
(0.5937) \\
\end{array}$ & $\begin{array}{c}0.0271 \\
(0.9707) \\
\end{array}$ \\
\hline $\mathrm{W}^{*}$ Institution & $\begin{array}{c}0.0676 \\
(0.6961) \\
\end{array}$ & $\begin{array}{c}0.1118 \\
(1.2608) \\
\end{array}$ & $\begin{array}{c}0.1126 \\
(1.3557) \\
\end{array}$ & $\begin{array}{l}0.1774^{* *} \\
(2.0770) \\
\end{array}$ & $\begin{array}{l}0.1896^{* *} \\
(2.2482) \\
\end{array}$ \\
\hline $\mathrm{W}^{*}$ Education & $\begin{array}{c}-0.0283 \\
(-0.8274) \\
\end{array}$ & $\begin{array}{c}-0.0354 \\
(-1.0392) \\
\end{array}$ & $\begin{array}{c}-0.0201 \\
(-0.5825) \\
\end{array}$ & $\begin{array}{c}-0.0213 \\
(-0.6237) \\
\end{array}$ & $\begin{array}{c}-0.0271 \\
(-0.7981) \\
\end{array}$ \\
\hline $\mathrm{W}^{*}$ Innovation & $\begin{array}{c}0.2119^{* * *} \\
(5.2661) \\
\end{array}$ & $\begin{array}{c}0.2078^{* * *} \\
(5.1659) \\
\end{array}$ & $\begin{array}{c}0.2330^{* * *} \\
(5.8436) \\
\end{array}$ & $\begin{array}{c}0.2330^{* * *} \\
(5.8432) \\
\end{array}$ & $\begin{array}{c}0.2219^{* * *} \\
(5.5461) \\
\end{array}$ \\
\hline$\delta^{2}$ & 0.1684 & 0.1664 & 0.1685 & 0.1674 & 0.1652 \\
\hline$\overline{R^{2}}$ & 0.6511 & 0.6557 & 0.6502 & 0.6521 & 0.6574 \\
\hline Log-L & -896.3932 & -884.6521 & -898.3479 & -892.1746 & -878.3045 \\
\hline
\end{tabular}

Note. ${ }^{* * *},{ }^{* *}$, and ${ }^{*}$ denote a significance level of $1 \%, 5 \%$, and $10 \%$, respectively, and the $t$-statistic is in parentheses. For the same reasons as above, the regression results based on $\mathrm{stF}$ are reported here. 
Heilongjiang, Anhui, Jiangxi, Henan, Hubei, and Hunan. The Western cities are located in Inner Mongolia, Guangxi, Sichuan, Guizhou, Yunnan, Shaanxi, Gansu, Qinghai, Ningxia, and Xinjiang). Columns 2 to 4 of Table 10 show the estimated results when considering the heterogeneity of the city location. It can be found that both subsidies and tax preferences can enhance the innovation quality of the Middle and Western cities but hinder that of the Eastern cities, which confirms Hypothesis 3. The Eastern cities are more market-oriented and face relatively less market failure. Therefore, government R\&D subsidies are likely to be redundant resources for them, which may cause government failure, and thus, they are not conducive to innovation quality. In addition, consistent with $\mathrm{Wu}$ et al. [63], the tax burden stimulates innovation in the Eastern cities. Overall, in innovation, the Eastern cities rely more on the market, while the Middle and Western cities rely more on the government, which is consistent with $\mathrm{Xu}$ and Huang [64].

5.1.2. Heterogeneity of the City Administrative Hierarchy. There are 31 higher-administrative-hierarchy cities and 252 general-administrative-hierarchy cities among the 283 cities (this study defines higher-administrative-hierarchy cities as either provincial capitals or subprovincial cities, namely, Shijiazhuang, Taiyuan, Hohhot, Shenyang, Dalian, Changchun, Harbin, Nanjing, Hangzhou, Ningbo, Hefei, Fuzhou, Xiamen, Nanchang, Qingdao, Jinan, Zhengzhou, Wuhan, Changsha, Guangzhou, Shenzhen, Nanning, Haikou, Chengdu, Guiyang, Kunming, Xi'an, Lanzhou, Xining, Yinchuan, and Urumqi. And, general-administrative-hierarchy cities are cities other than those listed above). Columns 5 and 6 of Table 7 present the estimated results when considering the heterogeneity of the city administrative hierarchy. It can be found that subsidies and tax preferences are detrimental to improving the regional innovation quality of higher-administrative-hierarchy cities but are favorable to general-administrative-hierarchy cities, which confirms Hypothesis 4. Although China's R\&D funding policy of "picking the winners" favors firms located in the developed areas [4], the results achieved are not satisfactory. It may be because provincial capitals and subprovincial cities already have advantages in acquiring innovation resources, and the government's intervention through $\mathrm{R} \& \mathrm{D}$ funding may cause them to be crowded with funds and talents, which reduces the allocation efficiency of innovation resources and is not conducive to improving their regional innovation quality.

5.2. Impact of Government R\&D Funding on the Regional Innovation Quality Gap. The results of the heterogeneity test above indicate that government R\&D funding is beneficial to the improvement of regional innovation quality in the Middle and Western cities and the general-administrative- hierarchy cities. It indicates that the regional innovation quality in regions without innovation advantages has been improved with the help of government R\&D funding. Meanwhile, considering the current decreasing trend of the innovation quality gap in China (by calculating the Thiel index for 283 cities, it is found that the innovation quality gap shows a fluctuating downward trend during the sample period. And, the Thiel indices of regional innovation quality for 2011, 2012, 2013, 2014, 2015, 2016, and 2017 are 0.164, $0.137,0.134,0.128,0.130,0.136$, and 0.110 , respectively), whether government R\&D funding can narrow the regional innovation quality gap?

This study establishes an SDM to investigate the influence of government R\&D funding on the regional innovation quality gap. In this model, the dependent variable is the regional innovation quality gap, the independent variables are the two types of government R\&D funding (i.e., subsidies and tax preferences), and the control variables are consistent with the previous section. Moreover, the regional innovation quality gap is expressed as the regional innovation quality in a city in a particular year minus the minimum value of regional innovation quality in all cities in that year. This study expects a negative sign for subsidies and a positive sign for tax preferences.

Table 11 reports the estimated results. This study focuses on stF when analyzing for the same reasons mentioned earlier. It shows that the coefficient of subsidies is significantly positive and that of tax preferences, although positive, does not pass the significance test, which is inconsistent with our expectations. It indicates that government $\mathrm{R} \& \mathrm{D}$ funding cannot reduce the regional innovation quality gap but widen it instead. The reason may be that currently, government R\&D funding has been heavily concentrated in the Eastern cities and general-administrative-hierarchy cities. Still, funding for these cities has not had the desired effect. Meanwhile, the Middle and Western cities and generaladministrative-hierarchy cities with positive effects have received less government $\mathrm{R} \& \mathrm{D}$ funding. For example, in 2017, the minimum value of S\&T expenditures as a share of GDP in the Eastern cities was $0.03 \%$, while that in the Middle and Western cities was $0.02 \%$, a difference of 1.5 times; the minimum value in higher-administrative-hierarchy cities was $0.08 \%$, while that in general-administrative-hierarchy cities was only $0.02 \%$, with a difference of 4 times. Furthermore, the Middle and Western cities and the generaladministrative-hierarchy cities have negative aggregate profits of industrial enterprises above the state-designated scale in some years. In this situation, their tax liabilities are lower, which may not be conducive to tax preferences in enhancing the innovation quality in these regions, thus not closing the gap of regional innovation quality. The above analysis shows that there is "insufficient intervention" in the regions with good effects and "excessive intervention" in the 
TABLE 11: Results of the impact of government R\&D funding on the regional innovation quality gap.

\begin{tabular}{|c|c|c|c|c|c|}
\hline & nonF & sF & $\mathrm{tF}$ & $\mathrm{stF}$ & $r$ \\
\hline Intercept & $\begin{array}{c}-6.7792^{* * *} \\
(-5.9751) \\
\end{array}$ & - & - & - & - \\
\hline Subsidy & $\begin{array}{c}0.1285^{* * * *} \\
(4.7125) \\
\end{array}$ & $\begin{array}{c}0.1518^{* * * *} \\
(5.1990) \\
\end{array}$ & $\begin{array}{c}0.1386^{* * * *} \\
(5.0752) \\
\end{array}$ & $\begin{array}{c}0.1617^{* * * *} \\
(6.0032) \\
\end{array}$ & $\begin{array}{c}0.1389^{* * * *} \\
(5.0967) \\
\end{array}$ \\
\hline Tax & $\begin{array}{l}0.0728^{*} \\
(1.7777) \\
\end{array}$ & $\begin{array}{c}0.0583 \\
(1.3111) \\
\end{array}$ & $\begin{array}{c}0.0592 \\
(1.4466) \\
\end{array}$ & $\begin{array}{c}0.0453 \\
(1.1069) \\
\end{array}$ & $\begin{array}{c}0.0591 \\
(1.4443) \\
\end{array}$ \\
\hline Resources & $\begin{array}{l}0.3691^{* * *} \\
(15.8769)\end{array}$ & $\begin{array}{l}0.3551^{* * *} \\
(13.8574) \\
\end{array}$ & $\begin{array}{l}0.3721^{* * *} \\
(16.0003) \\
\end{array}$ & $\begin{array}{c}0.3575^{* * *} \\
(15.1131) \\
\end{array}$ & $\begin{array}{l}0.3719^{* * *} \\
(16.0157) \\
\end{array}$ \\
\hline Support & $\begin{array}{c}0.1388^{* * *} \\
(3.0155) \\
\end{array}$ & $\begin{array}{c}0.1845^{* * *} \\
(3.6823) \\
\end{array}$ & $\begin{array}{c}0.1423^{* * *} \\
(3.0996) \\
\end{array}$ & $\begin{array}{c}0.1906^{* * *} \\
(4.1352) \\
\end{array}$ & $\begin{array}{c}0.1430^{* * *} \\
(3.1192) \\
\end{array}$ \\
\hline Economy & $\begin{array}{c}0.3719^{* * *} \\
(8.0881) \\
\end{array}$ & $\begin{array}{c}0.3852^{* * *} \\
(7.7766) \\
\end{array}$ & $\begin{array}{c}0.3866^{* * *} \\
(8.4449) \\
\end{array}$ & $\begin{array}{c}0.4012^{* * *} \\
(8.8193) \\
\end{array}$ & $\begin{array}{c}0.3868^{* * *} \\
(8.4641) \\
\end{array}$ \\
\hline Industry & $\begin{array}{c}0.0368 \\
(0.5221) \\
\end{array}$ & $\begin{array}{c}0.0026 \\
(0.0347) \\
\end{array}$ & $\begin{array}{c}0.0371 \\
(0.5261) \\
\end{array}$ & $\begin{array}{c}0.0025 \\
(0.0364) \\
\end{array}$ & $\begin{array}{c}0.0367 \\
(0.5214) \\
\end{array}$ \\
\hline Size & $\begin{array}{c}0.0278 \\
(0.8957) \\
\end{array}$ & $\begin{array}{c}0.0238 \\
(0.7251) \\
\end{array}$ & $\begin{array}{c}0.0196 \\
(0.6312) \\
\end{array}$ & $\begin{array}{c}0.0131 \\
(0.4303) \\
\end{array}$ & $\begin{array}{c}0.0195 \\
(0.6311) \\
\end{array}$ \\
\hline Infrastructure & $\begin{array}{c}-0.0228 \\
(-0.6208) \\
\end{array}$ & $\begin{array}{c}-0.0241 \\
(-0.6155) \\
\end{array}$ & $\begin{array}{c}-0.0136 \\
(-0.3697) \\
\end{array}$ & $\begin{array}{l}-0.0151 \\
(-0.4169) \\
\end{array}$ & $\begin{array}{c}-0.0136 \\
(-0.3720) \\
\end{array}$ \\
\hline Opening & $\begin{array}{c}0.0278 \\
(1.6417) \\
\end{array}$ & $\begin{array}{c}0.0296 \\
(1.6186) \\
\end{array}$ & $\begin{array}{l}0.0309^{*} \\
(1.8275) \\
\end{array}$ & $\begin{array}{l}0.0326^{*} \\
(1.9384) \\
\end{array}$ & $\begin{array}{l}0.0309^{*} \\
(1.8327) \\
\end{array}$ \\
\hline Institution & $\begin{array}{c}-0.1809^{* * *} \\
(-3.3995) \\
\end{array}$ & $\begin{array}{c}-0.2011^{* * *} \\
(-3.4945)\end{array}$ & $\begin{array}{c}-0.1699^{* * *} \\
(-3.2029) \\
\end{array}$ & $\begin{array}{c}-0.1891^{* * *} \\
(-3.5742) \\
\end{array}$ & $\begin{array}{c}-0.1702^{* * *} \\
(-3.2150) \\
\end{array}$ \\
\hline Education & $\begin{array}{l}0.0331^{*} \\
(1.9007) \\
\end{array}$ & $\begin{array}{c}0.0371^{* *} \\
(1.9940) \\
\end{array}$ & $\begin{array}{l}0.0301^{*} \\
(1.7310) \\
\end{array}$ & $\begin{array}{c}0.0335^{* *} \\
(1.9543) \\
\end{array}$ & $\begin{array}{l}0.0301^{*} \\
(1.7381) \\
\end{array}$ \\
\hline $\mathrm{W}^{*}$ Subsidy & $\begin{array}{c}-0.0248 \\
(-0.4525) \\
\end{array}$ & $\begin{array}{c}-0.0146 \\
(-0.2530) \\
\end{array}$ & $\begin{array}{c}0.0638 \\
(0.9644) \\
\end{array}$ & $\begin{array}{c}0.0899 \\
(1.3782) \\
\end{array}$ & $\begin{array}{c}0.0639 \\
(0.9681) \\
\end{array}$ \\
\hline $\mathrm{W}^{*} \operatorname{Tax}$ & $\begin{array}{c}0.0188 \\
(-0.2385) \\
\end{array}$ & $\begin{array}{c}0.0391 \\
(0.4724) \\
\end{array}$ & $\begin{array}{c}-0.1404 \\
(-1.3641) \\
\end{array}$ & $\begin{array}{c}-0.0582 \\
(-0.5739) \\
\end{array}$ & $\begin{array}{c}-0.1393 \\
(-1.3562) \\
\end{array}$ \\
\hline $\mathrm{W}^{*}$ Resources & $\begin{array}{c}-0.0475 \\
(-0.7696) \\
\end{array}$ & $\begin{array}{l}-0.0653 \\
(0.3087)\end{array}$ & $\begin{array}{c}0.0007 \\
(-1.3641) \\
\end{array}$ & $\begin{array}{c}-0.0234 \\
(-0.5739) \\
\end{array}$ & $\begin{array}{c}0.0001 \\
(0.0013) \\
\end{array}$ \\
\hline $\mathrm{W}^{*}$ Support & $\begin{array}{c}-0.1181 \\
(-1.2995)\end{array}$ & $\begin{array}{c}-0.2058^{* *} \\
(-2.1011) \\
\end{array}$ & $\begin{array}{l}-0.0157 \\
(3.0996) \\
\end{array}$ & $\begin{array}{c}-0.0651 \\
(-0.5982) \\
\end{array}$ & $\begin{array}{c}-0.0166 \\
(-0.1523) \\
\end{array}$ \\
\hline $\mathrm{W}^{*}$ Economy & $\begin{array}{c}-0.2519^{* *} \\
(-2.4265) \\
\end{array}$ & $\begin{array}{c}-0.2657^{* *} \\
(-0.9681) \\
\end{array}$ & $\begin{array}{c}0.0151 \\
(0.1322) \\
\end{array}$ & $\begin{array}{c}0.0356 \\
(0.3178) \\
\end{array}$ & $\begin{array}{c}0.0144 \\
(0.1278) \\
\end{array}$ \\
\hline $\mathrm{W}^{*}$ Industry & $\begin{array}{c}-0.0043 \\
(-0.0276) \\
\end{array}$ & $\begin{array}{c}0.0471 \\
(0.7326) \\
\end{array}$ & $\begin{array}{c}-0.0302 \\
(-0.1673) \\
\end{array}$ & $\begin{array}{c}-0.0265 \\
(-0.5739) \\
\end{array}$ & $\begin{array}{c}-0.0303 \\
(-0.1681) \\
\end{array}$ \\
\hline $\mathrm{W}^{*}$ Size & $\begin{array}{c}-0.0109 \\
(-0.1720) \\
\end{array}$ & $\begin{array}{l}-0.0689 \\
(0.7326) \\
\end{array}$ & $\begin{array}{l}-0.1291^{*} \\
(-1.6761) \\
\end{array}$ & $\begin{array}{c}-0.1191 \\
(-1.5597) \\
\end{array}$ & $\begin{array}{l}-0.1288^{*} \\
(-1.6750) \\
\end{array}$ \\
\hline $\mathrm{W}^{*}$ Infrastructure & $\begin{array}{c}-0.0441 \\
(-0.5216)\end{array}$ & $\begin{array}{c}-0.0141 \\
(-0.1562) \\
\end{array}$ & $\begin{array}{c}0.0614 \\
(-0.3697) \\
\end{array}$ & $\begin{array}{c}0.0818 \\
(0.8697) \\
\end{array}$ & $\begin{array}{c}0.0616 \\
(-0.1523) \\
\end{array}$ \\
\hline $\mathrm{W}^{*}$ Opening & $\begin{array}{c}0.0159 \\
(0.3987) \\
\end{array}$ & $\begin{array}{c}0.0082 \\
(0.1912) \\
\end{array}$ & $\begin{array}{c}0.0352 \\
(1.8275) \\
\end{array}$ & $\begin{array}{c}0.0331 \\
(0.7978) \\
\end{array}$ & $\begin{array}{c}0.0352 \\
(0.8474) \\
\end{array}$ \\
\hline $\mathrm{W}^{*}$ Institution & $\begin{array}{c}0.1142 \\
(1.0344) \\
\end{array}$ & $\begin{array}{c}0.0426 \\
(0.7326)\end{array}$ & $\begin{array}{l}0.2468^{* *} \\
(2.0492)\end{array}$ & $\begin{array}{c}0.1872 \\
(1.5698) \\
\end{array}$ & $\begin{array}{c}0.2463^{* *} \\
(2.0496) \\
\end{array}$ \\
\hline $\mathrm{W}^{*}$ Education & $\begin{array}{c}0.0095 \\
(0.2235) \\
\end{array}$ & $\begin{array}{c}-0.0021 \\
(-0.0469) \\
\end{array}$ & $\begin{array}{c}-0.0179 \\
(-0.3605) \\
\end{array}$ & $\begin{array}{c}-0.0333 \\
(-0.6661) \\
\end{array}$ & $\begin{array}{c}-0.0183 \\
(-0.3679) \\
\end{array}$ \\
\hline $\mathrm{W}^{*}$ Innovation & $\begin{array}{c}0.1889^{* * *} \\
(4.6270) \\
\end{array}$ & $\begin{array}{c}0.1819^{* * *} \\
(4.4440)\end{array}$ & $\begin{array}{c}0.1199^{* * *} \\
(2.8813) \\
\end{array}$ & $\begin{array}{c}0.0999^{* *} \\
(2.3884)\end{array}$ & $\begin{array}{c}0.1209^{* * *} \\
(2.9058) \\
\end{array}$ \\
\hline Theta & - & - & - & - & $\begin{array}{l}0.9917^{* * *} \\
(21.9495) \\
\end{array}$ \\
\hline $\begin{array}{l}\frac{\delta^{2}}{R^{2}} \\
\text { Log-L }\end{array}$ & $\begin{array}{c}0.4303 \\
0.5176 \\
-1980.7821\end{array}$ & $\begin{array}{c}0.4295 \\
0.5363 \\
-1836.7633\end{array}$ & $\begin{array}{c}0.4251 \\
0.5141 \\
-1962.3415\end{array}$ & $\begin{array}{c}0.3606 \\
0.5338 \\
-1802.9891\end{array}$ & $\begin{array}{c}0.4225 \\
0.5141 \\
-2386.0721\end{array}$ \\
\hline
\end{tabular}

Note. $^{* * *},{ }^{* *}$, and ${ }^{*}$ denote a significance level of $1 \%, 5 \%$, and $10 \%$, respectively. The $t$-statistic is in parentheses. 
regions with poor effects, resulting in government $R \& D$ funding failing to meet the expectations of reducing the regional innovation quality gap but instead widening it.

\section{Conclusions and Implications}

Based on 283 Chinese cities from 2011 to 2017 and the basic connotation of regional innovation quality, this study empirically analyzes the impact of government $R \& D$ funding on regional innovation quality and its influence mechanism. Furthermore, it analyses the heterogeneity of government $R \& D$ funding affecting regional innovation quality and explores whether government $\mathrm{R} \& \mathrm{D}$ funding can narrow the regional innovation quality gap. This paper finds a positive spatial correlation between regional innovation qualities; the improvement of local innovation quality can promote the innovation quality in neighboring regions. Subsidies can significantly improve the innovation quality in local and neighboring regions, whereas the effect of tax preferences on regional innovation quality is not significant. The above results remain robust when accounting for possible lags in government $R \& D$ funding, replacing the measurements of government R\&D funding and the spatial weighting matrix. The analysis of the mechanism reveals that subsidies are conducive to increasing the investment of innovation resources by local direct innovation subjects and innovation support of indirect innovation subjects and attracting the inflow of innovation resources from close regions, thus contributing to the improvement of regional innovation quality. Simultaneously, there is spatial competition for subsidies, which makes them conducive to improving the innovation quality in neighboring regions. Moreover, when considering the city location's heterogeneity, it is found that government R\&D funding cannot improve the innovation quality in the Eastern cities but improve that in the Middle and Western cities. When considering the heterogeneity of the city administrative hierarchy, it finds that government R\&D funding cannot improve the innovation quality in the higher-administrative-hierarchy cities but improve that in the general-administrative-hierarchy cities. Further, after receiving government $\mathrm{R} \& \mathrm{D}$ funding, cities without innovation advantages, such as the Middle and Western cities and the general-administrative-hierarchy cities, have not narrowed the innovation quality gap with the Eastern cities and higher-administrative-hierarchy cities.

Based on this, the paper draws the following research implications.

Firstly, improve subsidy policies and enhance the intensity of subsidies. This study shows that subsidies are conducive to improving regional innovation quality by increasing the input of innovation resources by direct innovation subjects, increasing the innovation support of indirect innovation subjects, and attracting the inflow of innovation resources from other regions. Therefore, when formulating relevant strategies and plans, the central government should actively carry out and appropriately strengthen subsidies. At the same time, to better utilize the policy effect, the government should improve the screening system before the implementation of subsidies and the information disclosure and the tracking management system after the implementation of subsidies. Moreover, spatial competition for subsidies makes innovation resources tend to flow into regions with larger subsidies, so the central government should actively guard against the possible vicious competition for subsidies by local governments.

Secondly, optimize preferential tax policies to stimulate high-quality innovation outcomes. The study finds that tax preferences on regional innovation quality are not significant on the whole, but are conducive to improving the regional innovation quality in the Middle and Western cities and general-administrative-hierarchy cities. Therefore, the government needs to further optimize and improve preferential tax policies. For example, the government can increase the tax deduction of the income from the patent assignment. It may not only encourage innovation subjects to actively apply for patents to protect innovation achievements but also reduce the assignment cost, improve the transfer income, and stimulate the transfer enthusiasm to improve regional innovation quality. At the same time, the strength of tax preferences is influenced by the amount of enterprise income tax payable so that innovation subjects should focus on improving their business performance and carry out reasonable tax planning in their daily operation to maximize the positive effect of tax preferences on regional innovation quality.

Thirdly, implement government R\&D funding policies according to local conditions and cities. The study shows that government R\&D funding cannot improve the innovation quality in the Eastern cities and higher-administrative-hierarchy cities, while it can improve that in Middle and Western cities and general-administrative-hierarchy cities. Therefore, government $\mathrm{R} \& \mathrm{D}$ funding should be more targeted and flexible, especially against the background of tightening revenue and pressure on fiscal expenditure. In addition, due to both existences of "underintervention" and "overintervention," government R\&D funding fails to narrow the gap of regional innovation quality. This further suggests that the government should focus on increasing $\mathrm{R} \& \mathrm{D}$ funding for regions with innovation disadvantages so that government R\&D funding can improve regional innovation quality and also help reduce the regional innovation quality gap.

\section{Data Availability}

The data used to support the findings of this study are available from the corresponding author upon request.

\section{Conflicts of Interest}

The authors declare that they have no conflicts of interest.

\section{Acknowledgments}

This study was supported by the National Natural Science Foundation (71573138), Jiangsu Social Science Foundation (16JD005), Jiangsu, Provincial Soft Science Project 
(BR2019048), and Major Research Projects of Philosophy and Social Sciences in Universities of Jiangsu Province.

\section{References}

[1] Q. Chen, S. Lin, and X. Zhang, "The effect of China's incentive policies for technological innovation: incentivizing quantity or quality," China Industrial Economics, vol. 4, pp. 79-96, 2020.

[2] P. A. David, B. H. Hall, and A. A. Toole, "Is public R\&D a complement or substitute for private $\mathrm{R} \& \mathrm{D}$ ? a review of the econometric evidence," Research Policy, vol. 29, no. 4-5, pp. 497-529, 2000.

[3] R. Bronzini and E. Iachini, "Are incentives for R\&D effective? evidence from a regression discontinuity approach," American Economic Journal: Economic Policy, vol. 6, no. 4, pp. 100-134, 2014.

[4] P. Boeing, "The allocation and effectiveness of China's R\&D subsidies-evidence from listed firms," Research Policy, vol. 45, no. 9, pp. 1774-1789, 2016.

[5] J. Zhang and W. Zheng, "Has catch-up strategy of innovation inhibited the quality of China's patents?" Economic Research Journal, vol. 53, no. 5, pp. 28-41, 2018.

[6] C. Xu, Y. Pang, and D. Liu, "Local fiscal pressure and government expenditure efficiency: the reform of income tax sharing as a quasi-natural experiment," Economic Research Journal, vol. 55, no. 6, pp. 138-154, 2020.

[7] I. Guceri, "Will the real R\&D employees please stand up? effects of tax breaks on firm-level outcomes," International Tax and Public Finance, vol. 25, no. 1, pp. 1-63, 2017.

[8] J. Choi and J. Lee, "Repairing the R\&D market failure: public $\mathrm{R} \& \mathrm{D}$ subsidy and the composition of private $\mathrm{R} \& \mathrm{D}$," Research Policy, vol. 46, no. 8, pp. 1465-1478, 2017.

[9] F. Yu, Y. Guo, K. Le-Nguyen, S. J. Barnes, and W. Zhang, "The impact of government subsidies and enterprises' R\&D investment: a panel data study from renewable energy in China," Energy Policy, vol. 89, pp. 106-113, 2016.

[10] C. Dimos and G. Pugh, "The effectiveness of R\&D subsidies: a meta-regression analysis of the evaluation literature," Research Policy, vol. 45, no. 4, pp. 797-815, 2016.

[11] W. Li and M. Zheng, "Is it substantive innovation or strategic innovation? - - impact of macroeconomic policies on microenterprises' innovation," Economic Research Journal, vol. 51, no. 4, pp. 60-73, 2016.

[12] J. Dang and K. Motohashi, "Patent statistics: a good indicator for innovation in China? patent subsidy program impacts on patent quality," China Economic Review, vol. 35, no. 9, pp. 137-155, 2015.

[13] C. Ernst, K. Richter, and N. Riedel, "Corporate taxation and the quality of research and development," International Tax and Public Finance, vol. 21, no. 4, pp. 694-719, 2014.

[14] A. Mukherjee, M. Singh, and A. Žaldokas, "Do corporate taxes hinder innovation?" Journal of Financial Economics, vol. 124, no. 1, pp. 195-221, 2017.

[15] U. Akcigit, J. Grigsby, T. Nicholas et al., "Taxation and innovation in the 20th century," NBER Working Paper Series, vol. 2018, p. 125, 2018.

[16] S. Lu and P. Liu, "Fiscal expenditure and regional innovation quality: an empirical analysis based on provincial data in China," Journal of Macro-Quality Research, vol. 3, no. 1, pp. 93-101, 2015.

[17] T. Zheng, H. Wang, and S. Gan, "Tax incentives and innovation quality improvement_- based on the perspective of quantity growth and structural optimization," Modern Finance \& Economics, vol. 40, no. 1, pp. 29-40, 2020.

[18] J. Li and J. Xing, "Why is collaborative agglomeration of innovation so important for improving regional innovation capabilities? a perspective based on collaborative agglomeration of industry-university-research institution," Complexity, vol. 2020, Article ID 7049606, 21 pages, 2020.

[19] Y. Bian, L. Wu, and J. Bai, "Does the competition of fiscal S\&T expenditure improve the regional innovation performance? - - based on the perspective of R\&D factor flow," Public Finance Research, vol. 1, pp. 45-58, 2020.

[20] P. F. Burke and M. Reitzig, "Measuring patent assessment quality-analyzing the degree and kind of (in) consistency in patent offices' decision making," Research Policy, vol. 36, no. 9, pp. 1404-1430, 2007.

[21] C. Y. Tseng and L. Y. Wu, "Innovation quality in the automobile industry: measurement indicators and performance implications," International Journal of Technology Management, vol. 37, no. 1/2, pp. 162-177, 2007.

[22] Y. He, "Can R\&D investment promote the quality of innovation? - - the regulating role of venture capital," Economic Survey, vol. 36, no. 4, pp. 118-125, 2019.

[23] T. Makkonen and T. Inkinen, "Innovation quality in knowledge cities: empirical evidence of innovation award competitions in Finland," Expert Systems with Applications, vol. 41, no. 12, pp. 5597-5604, 2014.

[24] X. Bai, Y. Wang, and X. Su, "R\&D subsidies or tax incentives: an empirical analysis of government intervention on enterprise innovation performance and innovation quality," Science Research Management, vol. 40, no. 06, pp. 9-18, 2019.

[25] K. J. Arrow, "The economic implications of learning by doing," The Review of Economic Studies, vol. 29, no. 3, pp. 155-173, 1962.

[26] C. Dai and Y. Liu, "Comparative analysis of the impact of tax incentives and financial subsidies on corporate R\&D," Economic Science, vol. 3, pp. 58-71, 2008.

[27] Y. Yu and D. Liu, "The effect of the space outflow of China's regional innovation and the effect of the outflow of value chains: a study from the perspective of the innovative value chain and on the model of the panel of multidimensional space," Management World, vol. 7, pp. 6-20, 2013.

[28] J. Bai, K. Jiang, and J. Li, "Using stochastic frontier model to evaluate regional R\&D innovation efficiency in China," Management World, vol. 10, pp. 51-61, 2009.

[29] E. Y. Lee and B. C. Cin, "The effect of risk-sharing government subsidy on corporate R\&D investment: empirical evidence from Korea," Technological Forecasting and Social Change, vol. 77, no. 6, pp. 881-890, 2010.

[30] C. Y. Lee, "The differential effects of public R\&D support on firm R\&D: theory and evidence from multi-country data," Technovation, vol. 31, no. 5-6, pp. 256-269, 2011.

[31] T. H. Clausen, "Do subsidies have positive impacts on R\&D and innovation activities at the firm level?" Structural Change and Economic Dynamics, vol. 20, no. 4, pp. 239-253, 2009.

[32] M. P. Feldman and M. R. Kelley, "The ex-ante assessment of knowledge spillovers: government $\mathrm{R} \& \mathrm{D}$ policy, economic incentives and private firm behavior," Research Policy, vol. 35, no. 10 , pp. 1509-1521, 2006.

[33] R. Kleer, "Government R\&D subsidies as a signal for private investors," Research Policy, vol. 39, no. 10, pp. 1361-1374, 2010.

[34] K. Yu, "Market reform, technological progress and regional energy efficiency--based on panel data model analysis of 30 
provinces in China from 1997 to 2014," Microeconomics, vol. 11, pp. 79-93, 2017.

[35] D. Lu and L. Zhu, "Marketization level, industrial policy of strategic emerging industries and enterprise innovation," Industrial Economics Research, vol. 2, pp. 65-77, 2018.

[36] T. Jiang, K. Sun, and H. Nie, "Administrative rank, total factor productivity and resource misallocation in Chinese cities," Management World, vol. 34, no. 3, pp. 38-50+77+183, 2018.

[37] J. G. Williamson, "Regional inequality and the process of national development: a description of the patterns," Economic Development and Cultural Change, vol. 13, no. 4, pp. 1-84, 1965.

[38] C.-C. Au and J. V. Henderson, "How migration restrictions limit agglomeration and productivity in China," Journal of Development Economics, vol. 80, no. 2, pp. 350-388, 2006.

[39] D. Encaoua, D. Guellec, and C. Martínez, "Patent systems for encouraging innovation: lessons from economic analysis," Research Policy, vol. 35, no. 9, pp. 1423-1440, 2006.

[40] X. Zhou, L. Cheng, and H. Wang, "Does the higher the level of technological innovation, the better the firm's financial performance? - - an empirical study based on patent application data of listed pharmaceutical companies in China in 16 years," Financial Research, vol. 8, pp. 166-179, 2012.

[41] F. Fan, H. Lian, and S. Wang, "Can regional collaborative innovation improve innovation efficiency? An empirical study of Chinese cities," Growth and Change, vol. 51, no. 1, pp. 440-463, 2020.

[42] F. Fan, H. Lian, X. Liu et al., "Can environmental regulation promote urban green innovation efficiency? an empirical study based on Chinese cities," Journal of Cleaner Production, vol. 287, no. 3, pp. 1-10, 2021.

[43] T. Yang, L. Luo, and B. Xu, "The technical innovation effect of government subsidy: 'quantity change' or 'quality change'?" China Soft Science, vol. 10, pp. 52-61, 2018.

[44] X. Pan, Q. Liu, and X. Peng, "Evaluation and analysis of regional innovation ability in China based on overall entropy method," Operations Research and Management Science, vol. 24, no. 4, pp. 155-162, 2015.

[45] C. Wu and M. Deng, "Technological innovation, opening to the outside world and high-quality development of the Yangtze River Economic Belt," Science \& Technology Progress and Policy, vol. 36, no. 3, pp. 33-41, 2019.

[46] K. Zhang and L. Huang, "Government innovation preference and regional innovation capability: is the wish to repay the backfired?” Public Finance Research, vol. 4, pp. 66-82, 2020.

[47] C. Jia and W. Wang, "Financial subsidies, tax incentives and enterprise innovation performance--based on the intermediary effect of R\&D investment," Friends of Accounting, vol. 11, pp. 98-103, 2019.

[48] J. Lu and X. Wang, "The impact of low-carbon pilot policies on technological innovation in Chinese cities-_quasi-natural experiment based on low-carbon city pilot," Social Sciences Edition Journal of China University of Geosciences, vol. 19, no. 6, pp. 128-141, 2019.

[49] D. Czarnitzki and H. Hottenrott, "R\&D investment and financing constraints of small and medium-sized firms," Small Business Economics, vol. 36, no. 1, pp. 65-83, 2011.

[50] F. Xu, "Research on bank credit and enterprise innovation dilemma," China Industrial Economy, vol. 1, pp. 119-136, 2019.

[51] T. Altenburg, H. Schmitz, and A. Stamm, "Breakthrough? China's and India's transition from production to innovation," World Development, vol. 36, no. 2, pp. 325-344, 2008.
[52] W. S. Comanor, "Market structure, product differentiation, and industrial research," The Quarterly Journal of Economics, vol. 81, no. 4, pp. 639-657, 1967.

[53] H. Katrak, "Imports of technology, enterprise size and R\&Dbased production in a newly industrializing country: the evidence from Indian Enterprises," World Development, vol. 22 , no. 10 , pp. 1599-1608, 1994.

[54] A. Agrawal, A. Galasso, and A. Oettl, "Road and innovation," The Review of Economics and Statistics, vol. 99, no. 3, pp. 417-434, 2017.

[55] J. Bai and Y. Bian, "A research on space-autocorrelation of China's government R\&D subsidies," Science Research Management, vol. 37, no. 1, pp. 77-83, 2016.

[56] S. Hasanefendic, J. M. Birkholz, H. Horta, and P. van der Sijde, "Individuals in action: bringing about innovation in higher education," European Journal of Higher Education, vol. 7, no. 2, pp. 101-119, 2017.

[57] R. Moreno, R. Paci, and S. Usai, "Spatial spillovers and innovation activity in European regions," Environment and Planning A: Economy and Space, vol. 37, no. 10, pp. 17931812, 2005.

[58] J. P. Elhorst, "Specification and estimation of spatial panel data models," International Regional Science Review, vol. 26, no. 3, pp. 244-268, 2003.

[59] J. P. Elhorst, "Matlab software for spatial panels," International Regional Science Review, vol. 37, no. 3, pp. 389-405, 2014.

[60] J. Li, Q. Tan, and J. Bai, "Spatial measurement analysis of regional innovation production in China - - an empirical study based on static and dynamic spatial panel models," Management World, vol. 7, pp. 43-55+65, 2010.

[61] J. P. Lesage and R. K. Pace, "Spatial econometric modeling of origin-destination flows," Journal of Regional Science, vol. 48, no. 5, pp. 941-967, 2008.

[62] J. P. Lesage and R. K. Pace, Introduction to Spatial Econometrics, CRC Press Taylor \& Francis Group, Boca Raton, FL, USA, 2009.

[63] F. Wu, X. Yang, X. Long et al., "Will local taxes really suppress regional innovation? research on nonlinear Threshold effect based on government," Behavior Economic Review, vol. 4, pp. 84-100+145, 2018.

[64] P. Xu and S. Huang, "The difference of regional innovation capability in China: from the perspective of government and market," Finance \& Economics, vol. 2, pp. 79-91, 2020. 